\title{
Comprehensive Density Functional Theory Studies of Vibrational Spectra of Carbonates
}

\author{
Yurii N. Zhuravlev ${ }^{1}$ and Victor V. Atuchin $2,3,4, * \mathbb{D}$ \\ 1 Institute of Basic Sciences, Kemerovo State University, 650000 Kemerovo, Russia; zhur@kemsu.ru \\ 2 Research and Development Department, Kemerovo State University, 650000 Kemerovo, Russia \\ 3 Laboratory of Optical Materials and Structures, Institute of Semiconductor Physics, \\ SB RAS, 630090 Novosibirsk, Russia \\ 4 Laboratory of Semiconductor and Dielectric Materials, Novosibirsk State University, \\ 630090 Novosibirsk, Russia \\ * Correspondence: atuchin@isp.nsc.ru; Tel.: +7-(383)-3308889
}

Received: 22 October 2020; Accepted: 8 November 2020; Published: 17 November 2020

\begin{abstract}
Within the framework of the density functional theory (DFT) and the hybrid functional B3LYP by means of the CRYSTAL17 program code, the wavenumbers and intensities of normal oscillations of $\mathrm{MgCO}_{3}, \mathrm{CaCO}_{3}, \mathrm{ZnCO}_{3}, \mathrm{CdCO}_{3}$ in the structure of calcite; $\mathrm{CaMg}\left(\mathrm{CO}_{3}\right)_{2}, \mathrm{CdMg}\left(\mathrm{CO}_{3}\right)_{2}$, $\mathrm{CaMn}\left(\mathrm{CO}_{3}\right)_{2}, \mathrm{CaZn}\left(\mathrm{CO}_{3}\right)_{2}$ in the structure of dolomite; $\mathrm{BaMg}\left(\mathrm{CO}_{3}\right)_{2}$ in the structure of the norsethite type; and $\mathrm{CaCO}_{3}, \mathrm{SrCO}_{3}, \mathrm{BaCO}_{3}$, and $\mathrm{PbCO}_{3}$ in the structure of aragonite were calculated. Infrared absorption and Raman spectra were compared with the known experimental data of synthetic and natural crystals. For lattice and intramolecular modes, linear dependences on the radius and mass of the metal cation are established. The obtained dependences have predictive power and can be used to study solid carbonate solutions. For trigonal and orthorhombic carbonates, the linear dependence of wavenumbers on the cation radius $R_{\mathrm{M}}$ (or M-O distance) is established for the infrared in-plane bending mode: $786.2-65.88 \cdot R_{\mathrm{M}}$ and Raman in-plane stretching mode: $768.5-53.24 \cdot R_{\mathrm{M}}$, with a correlation coefficient of 0.87 .
\end{abstract}

Keywords: Density Functional Theory; normal vibrations; infrared spectra; Raman spectra; metal carbonates; cation radius

\section{Introduction}

Carbonates form an extensive class of chemical compounds containing the carbonate ion $\mathrm{CO}_{3}^{2-}$ as the main structural element $[1,2]$. In nature, carbonates are found in many minerals and play a crucial role in the carbon exchange of our planet [2-8]. Carbonate compounds are widely used in the construction industry, optics, and nanotechnology [9-15]. Appearance of the carbonate species due to chemical interaction with the atmosphere agents was detected at the surface of many oxide materials widely used in optical and electronic technologies [16-20]. In recent years, many artificial crystals of complex carbonates that have no analogues in nature were created [1]. Due to the specific features of the crystal structure, such materials, in many cases, are characterized by high birefringence, nonlinear optical properties, and transparency in the ultraviolet spectral range, which makes them perspective materials for use in optical devices in the UV range [21-27]. In this aspect, it is of particular importance to study the physicochemical properties of carbonates-in particular, the relationship between their structural and spectroscopic characteristics. According to this approach, this work is aimed at a systematic study of the relationship between the crystal structure and vibrational characteristics of a set of crystals of simple and binary anhydrous carbonates known in nature. Such minerals form several crystal-chemical families, which makes it possible to study the effects 
of cation substitution on the wavenumbers of vibrational modes within the framework of a single structural type. In the near future, with the accumulation of experimental data of complex carbonates, this algorithm can be extended to new families of complex artificial crystals.

Natural carbonates are composed of over 60 minerals [2]. Simple and double rock-forming carbonates can be divided into three main groups based on the similarity of structures: calcite, dolomite, and aragonite. The structures of these crystals are shown in Figure 1. Calcite is the most abundant of all carbonate minerals [28]. The triangular geometry $\mathrm{CO}_{3}^{2-}$ dominates in the structure of calcite, which leads to rhombohedral symmetry of the crystal lattice with the space group $R-3 c$. A primitive cell contains two formula units $(Z=2)$. Divalent cations are octahedrally coordinated by oxygen atoms (Figure 1a). The calcite group includes anhydrous carbonates with the general formula $\mathrm{MCO}_{3}\left(\mathrm{M}: \mathrm{Ca}^{2+}, \mathrm{Mg}^{2+}, \mathrm{Fe}^{2+}, \mathrm{Zn}^{2+}, \mathrm{Mn}^{2+}, \mathrm{Co}^{2+}, \mathrm{Ni}^{2+}\right.$ and $\left.\mathrm{Cd}^{2+}\right)$ : calcite $\left(\mathrm{CaCO}_{3}\right)$ [29], magnesite $\left(\mathrm{MgCO}_{3}\right)$ [30], siderite $\left(\mathrm{FeCO}_{3}\right)$ [31], smithsonite $\left(\mathrm{ZnCO}_{3}\right)$ [32], hodochrosite $\left(\mathrm{MnCO}_{3}\right)$ [33], spherocobaltite $\left(\mathrm{CoCO}_{3}\right)$ [34], gaspeite $\left(\mathrm{NiCO}_{3}\right)$ [35], and otavite $\left(\mathrm{CdCO}_{3}\right)$ [36]. The ability to form isomorphic mixtures is widespread among the minerals of the calcite series [37].

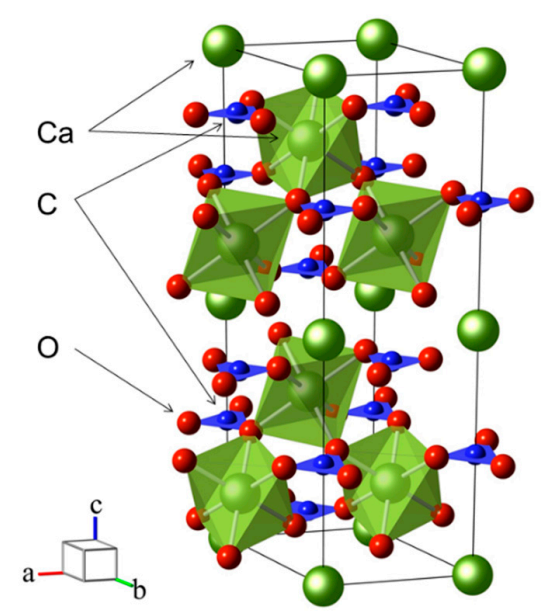

(a)

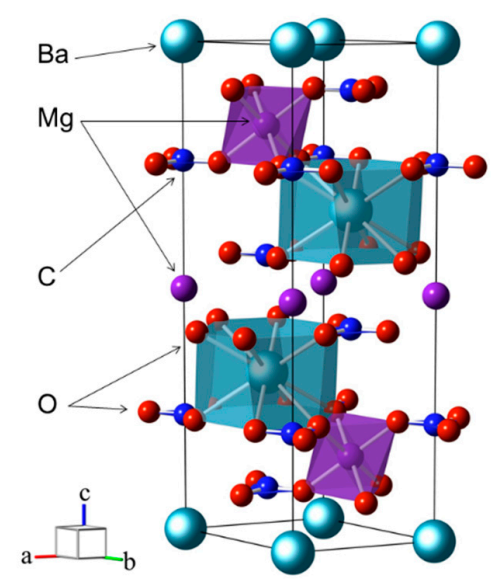

(c)

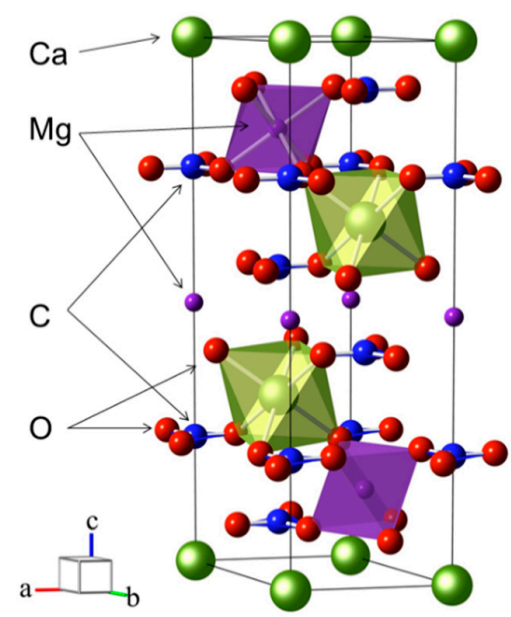

(b)

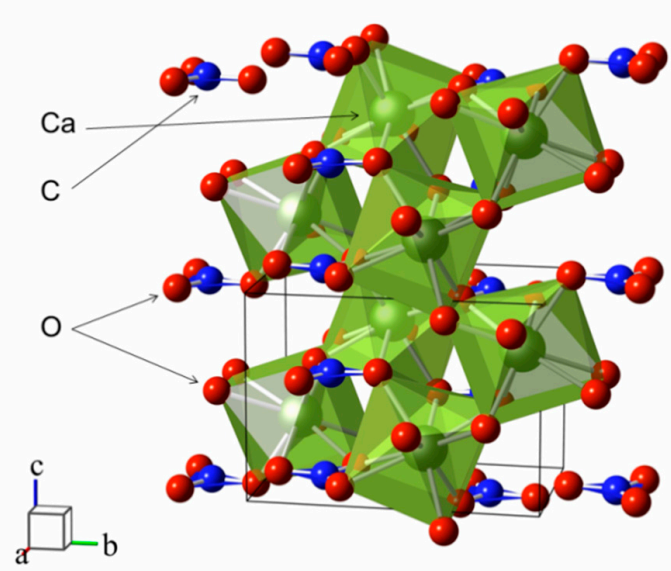

(d)

Figure 1. Fragments of the crystal structures of (a) $\mathrm{CaCO}_{3}$ (calcite), (b) $\mathrm{CaMg}\left(\mathrm{CO}_{3}\right)_{2}$ (dolomite), (c) $\mathrm{BaMg}\left(\mathrm{CO}_{3}\right)_{2}$ (norsethite) and (d) $\mathrm{CaCO}_{3}$ (aragonite) The unit cells are outlined. Lone atoms, excepting those in the unit cells, are omitted for clarity. 
One of the most common minerals is a double carbonate-dolomite $\left(\mathrm{CaMg}\left(\mathrm{CO}_{3}\right)_{2}\right)$ [38]. Dolomite is structured by natural minerals: minocordite $\left(\mathrm{CaZn}\left(\mathrm{CO}_{3}\right)_{2}\right)$ [39], ankerite $\left(\mathrm{CaFe}\left(\mathrm{CO}_{3}\right)_{2}\right)$ [40], and kutnohorite $\left.\mathrm{CaMn}\left(\mathrm{CO}_{3}\right)_{2}\right)$ [41]. Several crystals from the dolomite family were synthesized, including $\mathrm{CdMg}\left(\mathrm{CO}_{3}\right)_{2}, \mathrm{CdMn}\left(\mathrm{CO}_{3}\right)_{2}$, and $\mathrm{CdZn}\left(\mathrm{CO}_{3}\right)_{2}$ [42], and the structures were identified in [43]. Under ambient conditions, dolomite crystallizes in a rhombohedral structure with the space group $R-3$ $(\mathrm{Z}=2)$. Its layered structure consists of alternating $\left[\mathrm{CaO}_{6}\right]$ and $\left[\mathrm{MgO}_{6}\right]$ octahedra separated by nearly flat and parallel carbonate groups. The structure differs from calcite by the absence of a slip plane.

Double carbonates are also known in the structure of norsethite $\left(\mathrm{BaMg}\left(\mathrm{CO}_{3}\right)_{2}\right)$ [44] (Figure 1c). $\operatorname{BaMn}\left(\mathrm{CO}_{3}\right)_{2}$ does not exist in nature, but it was synthesized in [45]. The norsethite structure is described in $c$-space group $R$ - $3 c$ symmetry with doubled $c$-axis, which corresponds to different rotations of carbonate groups [46]. As the temperature rises in $\mathrm{BaMg}\left(\mathrm{CO}_{3}\right)_{2}$, a phase transition is observed from a phase stable under ambient conditions to a high-temperature structure, which is accompanied by a change in the symmetry $R-3 c \rightarrow R-3 m$. In the $R-3 m$ symmetry, the unit cell of $\mathrm{BaMg}\left(\mathrm{CO}_{3}\right)_{2}$ consists of the $\left[\mathrm{MgO}_{6}\right]$ octahedron, $\left[\mathrm{BaO}_{12}\right]$ polyhedron, and anions. Octahedra and polyhedra are in alternating layers, they are located exactly one above the other, parallel to the [001] direction and are separated by triangular groups $\mathrm{CO}_{3}^{2-}$. Natural isostructural orthorhombic carbonates are aragonite $\left(\mathrm{CaCO}_{3}\right)$ (Figure 1d), strontianite $\left(\mathrm{SrCO}_{3}\right)$, cerussite $\left(\mathrm{PbCO}_{3}\right)$, and witherite $\left(\mathrm{BaCO}_{3}\right)[47,48]$, listed in the order of increasing the size of the cation. In a crystal structure with the space group Pmcn $(Z=4)$,

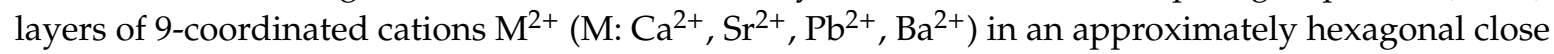
packing alternate with layers of planar $\mathrm{CO}_{3}^{2-}$ groups arranged perpendicular to the $c$-axis. Like calcites, aragonites form solid solutions [49]. Studies of isostructural orthorhombic carbonates are important for understanding phase transition sequences under pressure and temperature and, therefore, can provide insight into a carbon behavior in the Earth mantle [50-53].

The optical properties of natural carbonates were extensively explored since these widespread and cheap natural minerals can be used as raw resources for infrared technology materials [54]. In this regard, their infrared spectra (IRS) [55] and Raman spectra (RS) $[56,57]$ were previously studied experimentally and then theoretically [58,59]. Single crystals of iron-free magnesite were studied by Raman spectroscopy [30]; calcite and dolomite crystals were studied in [60] and all crystal were studied in [61]. In [62], they were evaluated with the methods of laser Raman spectroscopy and density functional theory (DFT) calculations using the plane wave basis (PW) and pseudopotentials of the Troullier-Martins type (TM PP). Otavite vibrational spectra were measured in experiment [63]. Eight natural carbonate minerals with a calcite structure were studied using Raman spectroscopy [64]. It was shown that changes in the wavenumber of phonon modes of the $E_{g}(\mathrm{~T})$ symmetry correlate with the distances between the nearest metal and oxygen atoms $\mathrm{M}-\mathrm{O}$ and the cation ionic radii. Using a graphical approach, the authors developed the spectroscopic Raman model to calculate the ionic radius of a divalent metal cation present in a mineral.

In [65], studies of the infrared spectra of natural iron-free dolomite were carried out. A combined study of infrared absorption and Raman scattering on a natural dolomite sample $\mathrm{CaMg}_{0.98} \mathrm{Fe}_{0.02}\left(\mathrm{CO}_{3}\right)_{2}$ was performed [66]. DFT using exchange correlation potentials in the local density approximation (LDA) and generalized gradient approximation (GGA) in the PW basis with TM PP were used here to interpret the obtained results. The Raman and infrared spectra of cerussite were measured and compared with the spectral characteristics of other minerals of the aragonite family [67]. RS and IRS at high temperature in situ were measured for aragonite, strontianite, cerussite, and witherite at atmospheric pressure [68]. Studies for high and medium temperature infrared absorption and Raman spectroscopy on a synthetic strontianite sample led to the construction of a pressure-temperature phase diagram [69]. In addition, here for the first time, the absorption spectra in the far infrared range were measured for the entire family of aragonite-type carbonates.

The works in which experimental and theoretical spectroscopic studies were performed for a group of carbonates with different structures are of particular interest. Thus, the purpose of the study [70] was to establish the influence of the $\mathrm{M}^{2+}$ cation type on the shift of positions of the absorption bands of 
various anhydrous carbonate minerals from the calcite and dolomite families. In this contribution, it is shown that the position of the minima of absorption bands is unique for each chemical composition of carbonates and can be a diagnostic indicator in mineralogy. A selection of the frequencies of intramolecular modes for a large number of carbonates is also found in [71]. In [72], infrared spectra in the wavenumber range of $70-650 \mathrm{~cm}^{-1}$ were presented for 18 common and rare minerals which are quite pure in composition and have a known crystal structure. It is shown that the spectra in the far infrared range of different carbonates from the same structural group have a pronounced similarity, and the observed shifts demonstrate the effect of changing the mass of cations. The vibrational modes of natural minerals_-aragonite, calcite, dolomite, magnesite, rhodochrosite, and siderite-that are active in the Raman spectrum were observed, and their pressure and temperature inducing frequency shifts were determined [73].

Thus, there are comparatively numerous experimental and individual theoretical studies of the vibrational spectra of carbonates in which the patterns of their changes during the substitution of cations were established for certain types of structures. However, systematic theoretical studies from a unified standpoint, carried out for all types of carbonate structures and having a predictive power in early works, are absent. The aim of this work is to theoretically study the dependences of the characteristics of the infrared and Raman spectra of carbonates crystallizing in the structures of calcite, dolomite, and aragonite on the radii and masses of metal cations. The parameters of vibrational spectra of carbonates were calculated within the framework of a unified approach based on the known experimental data of crystal structure. Furthermore, the results of our calculations were compared with the available experimental and theoretical parameters of the infrared and Raman spectra of carbonates and, on this basis, the general regularities of changes in the vibrational spectra were determined upon substitution of metal cations. Then, the information can be used as an instrument in the analysis of vibrational spectra of new crystalline compounds and solid solutions. The calculated quantitative dependences can also be used in noncontact nondestructive diagnostics of carbonates by spectroscopic techniques.

\section{Calculation Method}

The research of the ordinary optical properties dependences of metal carbonates were carried out within ab initio principles using the Hartree-Fock theory (HF) methods and density functional theory, which are well combined in the CRYSTAL17 program code [74,75]. The hybrid functional B3LYP, which includes the $20 \%$ HF exchange with the Becke exchange functional [76] and the LYP correlation functional [77], was used. The basic functions were chosen in the form of a linear combination of localized atomic orbitals of the Gaussian type. We used full-electronic basis sets for carbon, oxygen, magnesium, and calcium atoms from [78] and the gaussian basis sets of double-zeta valence with polarization quality basis set for zinc and cadmium atoms [79,80]. We used pseudopotential basis sets from [81] for strontium and barium, those of [82] for manganese, and those of [83] for lead.

The reciprocal space was sampled using a Monkhorst-Pack [84] grid with 216 independent $k$-points in the irreducible Brillouin zone for trigonal crystals, and 64 points for orthorhombic crystals. The accuracy of the self-matching procedure was no less than $10^{-9}$ a.u. $(1$ a.u. $=27.21 \mathrm{eV})$. The vibrational frequencies of the lattice atoms were calculated using the FREQCALC procedure $[85,86]$. The phonon harmonic frequencies $\omega_{\mathrm{p}}$ at the point $\Gamma(k=0$, the center of the first Brillouin zone) were obtained from the diagonalization of the mass-weighted Hessian matrix of the second derivatives of energy with respect to atomic displacements $u[87,88]$ :

$$
W_{a i, b j}^{G}=\frac{H_{a i, b j}^{0}}{\sqrt{M_{a} M_{b}}}, H_{a i, b j}^{0}=\left(\frac{\partial^{2} E}{\partial u_{a i}^{0} \partial u_{b j}^{0}}\right)
$$

where atoms $a$ and $b$ with masses $M_{a}$ and $M_{b}$ are displaced in the unit cell (index 0 ) from equilibrium positions along the $i$ - and $j$-Cartesian directions, respectively. The first order derivatives were 
calculated analytically, whereas the second order derivatives were obtained numerically. The intensity of IR absorption for the $v$-vibration was calculated using the Born effective charge tensor $Z^{*}$, which characterizes the change in dynamics and the electronic configuration of atom displacement. The relative intensities of the Raman peaks were calculated analytically using the extension scheme of the analytical calculation of IR intensity [89]. The proposed technique was previously used to study the ordinary properties of sulfates [90].

\section{Crystal Structure}

The crystal structure parameters of calcite, dolomite, norsethite, and aragonite types calculated in this work are shown in Table 1 . There is a close agreement between the optimized and experimental parameters of the crystal lattice. Thus, the standard deviation $\Delta=\sqrt{\frac{1}{N} \sum_{i=1}^{N}\left(\frac{\exp _{i}-\text { theor }_{i}}{\exp _{i}}\right)^{2}}$ for $N=5$ theoretical values from Table 1 and the experimental (exp) value for synthetic magnesite [30] is $1.6 \%$, for natural calcite [29] $-1.9 \%$, for smithsonite [32] $-1.5 \%$, for synthetic otavite [36] - 2.4\%, for dolomite [38]-1.5\%, and for norsethite [46]-3.6\%. For four crystals with aragonite structure, the deviation of three lattice constants and two interatomic distances from experimental data for natural minerals [48] is $2.7 \%$.

Table 1. Calculated lattice constants $a, b, c$, unit cell volume $V$, and average distances between the atoms of metal $\mathrm{M}$ and oxygen $\mathrm{O}\left(R_{\mathrm{M}-\mathrm{O}}\right)$ and carbon $\mathrm{C}$ and oxygen $\left(R_{\mathrm{C}-\mathrm{O}}\right)$.

\begin{tabular}{ccccccc}
\hline Carbonate & $\boldsymbol{a}, \mathbf{\AA}$ & $\boldsymbol{b}, \boldsymbol{\AA}$ & $\boldsymbol{c}, \mathbf{\AA}$ & $\boldsymbol{V}, \AA^{\mathbf{3}}$ & $\boldsymbol{R}_{\mathbf{M}-\mathbf{O}, \boldsymbol{\AA}}$ & $\boldsymbol{R}_{\mathbf{C}-\mathbf{O}, \boldsymbol{\mathbf { A }}}$ \\
\hline $\mathrm{MgCO}_{3}$ & 4.6624 & 4.6624 & 15.1891 & 285.9527 & 2.1229 & 1.2857 \\
$\mathrm{CaCO}_{3} \mathrm{C}$ & 5.0385 & 5.0385 & 17.3168 & 380.7118 & 2.3905 & 1.2878 \\
$\mathrm{ZnCO}_{3}$ & 4.7094 & 4.7094 & 15.1297 & 290.5952 & 2.1344 & 1.2973 \\
$\mathrm{CdCO}_{3}$ & 4.9819 & 4.9819 & 16.6163 & 357.1529 & 2.3312 & 1.2874 \\
$\mathrm{CaMg}_{\left(\mathrm{CO}_{3}\right)_{2}}$ & 4.8382 & 4.8382 & 16.2563 & 329.5605 & 2.2571 & 1.2865 \\
$\mathrm{CdMg}\left(\mathrm{CO}_{3}\right)_{2}$ & 4.8140 & 4.8140 & 15.8629 & 318.3695 & 2.2253 & 1.2862 \\
$\mathrm{CaMn}\left(\mathrm{CO}_{3}\right)_{2}$ & 4.8295 & 4.8295 & 15.8159 & 319.4686 & 2.2302 & 1.2874 \\
$\mathrm{CaZn}\left(\mathrm{CO}_{3}\right)_{2}$ & 4.8558 & 4.8558 & 16.2964 & 332.7782 & 2.2648 & 1.2866 \\
$\mathrm{BaMg}\left(\mathrm{CO}_{3}\right)_{2}$ & 5.0637 & 5.0637 & 17.0662 & 378.9683 & 2.6811 & 1.2846 \\
$\mathrm{CaCO}_{3} \mathrm{~A}$ & 5.0020 & 8.0175 & 5.8581 & 234.9323 & 2.5604 & 1.2857 \\
$\mathrm{SrCO} 3$ & 5.1469 & 8.4418 & 6.1947 & 269.1522 & 2.6838 & 1.2884 \\
$\mathrm{BaCO}_{3}$ & 5.3665 & 8.9327 & 6.6847 & 320.4459 & 2.8567 & 1.2910 \\
$\mathrm{PbCO}_{3}$ & 5.2453 & 8.5723 & 6.3725 & 286.5319 & 2.7451 & 1.2897 \\
\hline
\end{tabular}

As the physical quantities to describe the regularities of changes in the vibrational properties of carbonates from cationic substitution in the lattice, we used the mass of metal atoms (a.m.u.; Mg-23.985, $\mathrm{Ca}-39.963, \mathrm{Mn}-54.938, \mathrm{Zn}-63.929, \mathrm{Sr}-87.906, \mathrm{Cd}-113.904, \mathrm{Ba}-137.905$, and Pb-207.977) and the effective Shannon ionic radii [91]. The cationic radii of metals are determined by their electronic structure and depend on the coordination environment. The last filled electron shell of the magnesium ion is $2 p^{6}$, and the radius of $\mathrm{Mg}^{2+}$ surrounded by six nearest neighbors is $0.72 \AA$. Similarly, for calcium: $3 p^{6}, 1.00 \AA$. In zinc and cadmium, the filled shells are $3 d^{10}$ and $4 d^{10}$, and the radii are 0.74 and $0.95 \AA$, respectively. In aragonite, each $\mathrm{Ca}^{2+}$ ion is already surrounded by nine oxygen atoms and, therefore, its effective radius is $1.18 \AA$. In the case of strontium and barium, the radii for the 9-fold environment are 1.31 and $1.47 \AA$, and for $12-1.44,1.61 \AA$. The electronic configuration of lead [Xe] $4 f^{14} 5 d^{10} 6 s^{2} 6 p^{2}$ distinguishes it from other elements; therefore, the radius of 9-coordinated $\mathrm{Pb}^{2+}$ is $1.35 \AA$, which is larger than that of strontium, but smaller than that of barium. Transition metals have partially filled $3 d$ shells with the number of electrons from 5 to 8 , and decreasing radii for $\mathrm{Mn}^{2+}(0.83 \AA), \mathrm{Fe}^{2+}(0.78 \AA)$, and $\mathrm{Co}^{2+}(0.745 \AA)$. Following [33], we write the chemical formula of an arbitrary solid solution as $\mathrm{M} 1_{X 1} \mathrm{M} 2{ }_{X 2} \mathrm{M}_{X_{3}} \mathrm{CO}_{3}, X 1+X 2+X 3=1$. Then, the average radius of the cation is determined as $\left\langle R_{\mathrm{M}}\right\rangle$ $=X 1 \cdot R_{\mathrm{M} 1}+\mathrm{X} 2 \cdot R_{\mathrm{M} 2}+\mathrm{X} 3 \cdot R_{\mathrm{M} 3}$, where $R_{\mathrm{M} 1}, R_{\mathrm{M} 2}, R_{\mathrm{M} 3}$ are radii of divalent ions $\mathrm{M} 1^{2+}, \mathrm{M}^{2+}, \mathrm{M}^{2+}$. 
For dolomite, the cation radius is $0.86 \AA$, and for norsethite- $1.165 \AA$. The average atomic mass of metals is calculated in a similar way.

It is convenient to describe the change in crystal cell parameters or frequencies (intensities) of the vibrational spectra $y$ on the radii of cations or their masses $(r)$ using the linear dependence $y(r)=y_{0}+y_{1} \cdot r$, where $y_{0}$ is the value of the function at $r=0, y_{1}$-derivative of the function $y$, characterizing the rate of change of the corresponding value. The obtained calculated data $y\left(r_{\mathrm{i}}\right), I=1$, $N$ are approximated by a linear dependence (fit), and the accuracy of this procedure is controlled by the relation: $K=\sqrt{\sum_{i=1}^{N}\left(y_{i}^{f i t}-\overline{y^{f i t}}\right)^{2} / \sum_{i=1}^{N}\left(y_{i}^{\text {data }}-\overline{y^{\text {data }}}\right)^{2}}$, where the average value $\bar{y}=\frac{1}{N} \sum_{i=1}^{N} y_{i}$.

The change in the calculated unit cell volume of carbonates by one formula unit $V / Z$ from the cation radii $R_{\mathrm{M}}$ obeys the linear dependence $V / Z\left(\AA^{3}\right)=25.22+31.54 \cdot R_{\mathrm{M}}$ with a correlation coefficient of 0.936 . The large slope of this dependence of $31.54 \AA^{2}$ indicates that the replacement of the cation is of great importance for carbonates. The indicated dependence with the experimental values of volumes has the form $V / Z\left(\AA^{3}\right)=22.48+36.2482 \cdot R_{\mathrm{M}}\left(\AA^{3}\right)$ with the coefficient $K=0.945$. For each individual lattice type, the correlation coefficient is much better: for calcite and aragonite, 0.995 , and for dolomite, 0.969 . The linear dependence is explained by the fact that the cell volume is weakly related to the structure symmetry but is determined by the stacking of layers of polyhedrons, which depends on the ionic radii of the substitutional atoms. According to Vegard's law, the unit cell parameters change linearly depending on the composition, and for trigonal crystals, it can be written as: $a(\AA)=4.008+0.959 \cdot R_{\mathrm{M}}(0.941), c(\AA)=11.772+4.917 \cdot R_{\mathrm{M}}(0.88)$. Hereinafter, the coefficient $K$ is indicated in brackets. The linear dependence for all carbonates is fulfilled for the average distance between metal $\mathrm{M}$ and oxygen $\mathrm{O}: R_{\mathrm{M}-\mathrm{O}}(\AA)=1.374+1.02 \cdot R_{\mathrm{M}}(0.985)$ with high accuracy.

\section{Vibrational Spectra}

The rhombohedral cell of calcite contains ten atoms, and 30 possible vibrational modes can be classified for it, according to irreducible representations of the point group as: $\Gamma_{\text {tot }}=A_{1 \mathrm{~g}}(\mathrm{R})+3 A_{1 \mathrm{u}}+$ $3 A_{2 \mathrm{~g}}+3 A_{2 \mathrm{u}}(\mathrm{IR})+4 E_{\mathrm{g}}(\mathrm{R})+6 E_{\mathrm{u}}(\mathrm{IR}) \cdot A_{1 \mathrm{~g}}$ and $4 E_{\mathrm{g}}$ modes are active in Raman spectra (R), $3 A_{2 \mathrm{u}}$ and $5 E_{\mathrm{u}}$ modes are active in infrared (IR), $A_{1 \mathrm{u}}$ and $3 A_{2 \mathrm{~g}}$ modes are spectroscopically inactive, and $1 A_{2 \mathrm{u}}$ and $1 E_{\mathrm{u}}$ modes are acoustic. Nine translational modes will refer to the symmetry $A_{2 \mathrm{~g}}+A_{1 \mathrm{u}}+A_{2 \mathrm{u}}+$ $E_{\mathrm{g}}+2 E_{\mathrm{u}}$, six librational modes to $A_{2 \mathrm{~g}}+A_{2 \mathrm{u}}+E_{\mathrm{g}}+E_{\mathrm{u}}$, and twelve internal vibrations to $A_{1 \mathrm{~g}}+A_{2 \mathrm{~g}}+$ $A_{1 \mathrm{u}}+A_{2 \mathrm{u}}+2 E_{\mathrm{g}}+2 E_{\mathrm{u}}$. Modes of the $A_{2 \mathrm{u}}$ symmetry have polarization $E \| z$ and modes of $E_{\mathrm{u}}$ symmetry have $E \perp z$ polarization. Internal vibrations of $E_{\mathrm{u}}$ symmetry are of the $v_{4}$ type (in-plane bending), $A_{2 u}$ modes are of the $v_{2}$ type (out-of plane bending), and $E_{\mathrm{u}}$ symmetry are of the $v_{3}$ type of symmetric stretching. In the Raman spectrum, the $v_{4}$ (in-plane asymmetric stretching) mode has $E_{\mathrm{g}}$ symmetry, the $v_{1}$ symmetric stretch mode has $A_{1 \mathrm{~g}}$ symmetry, and a $v_{3}$ asymmetric stretch type has $E_{\mathrm{g}}$ symmetry.

For dolomite structure, the expansion of the vibrational representation according to irreducible representations is $\Gamma_{\text {tot }}=4 A_{\mathrm{g}}(\mathrm{R})+6 A_{\mathrm{u}}(\mathrm{IR})+4 E_{\mathrm{g}}(\mathrm{R})+6 E_{\mathrm{u}}(\mathrm{IR})$. Nine translational modes refer to symmetry $A_{\mathrm{g}}+2 A_{\mathrm{u}}+E_{\mathrm{g}}+2 E_{\mathrm{u}}$, six rotational modes refer to $A_{\mathrm{g}}+A_{\mathrm{u}}+E_{\mathrm{g}}+E_{\mathrm{u}}$, and 12 internal modes refer to $2 A_{\mathrm{g}}+2 A_{\mathrm{u}}+2 E_{\mathrm{g}}+2 E_{\mathrm{u}}$. For the norsethite type structure with the space group $R-3 m$, the expansion of the vibrational representation is: $\Gamma_{\text {tot }}=3 A_{1 \mathrm{~g}}(\mathrm{R})+2 A_{1 \mathrm{u}}+A_{2 \mathrm{~g}}+5 A_{2 \mathrm{u}}(\mathrm{IR})+4 E_{g}(\mathrm{R})+6 E_{u}(\mathrm{IR})$. For the aragonite orthorhombic structure, the symmetry of the carbonate group decreases to $C_{s}$. There will be 60 vibrational modes in total, where $1 B_{1 \mathrm{u}}+1 B_{2 \mathrm{u}}+1 B_{3 \mathrm{u}}$ are acoustic. The vibrational representation is decomposed into irreducible representations as $\Gamma_{\text {tot }}=9 A_{\mathrm{g}}+6 B_{1 \mathrm{~g}}(\mathrm{R})+9 B_{2 \mathrm{~g}}(\mathrm{R})+6 B_{3 \mathrm{~g}}(\mathrm{R})+6 A_{\mathrm{u}}$ $+9 B_{1 \mathrm{u}}(\mathrm{IR})+6 B_{2 \mathrm{u}}(\mathrm{IR})+9 B_{3 \mathrm{u}}(\mathrm{IR})$. The $B_{2 \mathrm{u}}$ symmetry modes have polarizations $\boldsymbol{E}\left\|\boldsymbol{x}(\boldsymbol{a}), B_{3 \mathrm{u}}-\boldsymbol{E}\right\| \boldsymbol{y}(\boldsymbol{b})$, $B_{1 \mathrm{u}}-E \| z(c)$. There will be 24 internal modes, eight of the $v_{4}$ and $v_{3}$ types, and four of the $v_{2}$ and $v_{1}$ types. The available experimental and theoretical data on vibration spectra of the carbonates under consideration are summarized in Supplementary Materials [92-110]. 


\section{Optical Spectra of Crystals with a Calcite Structure}

The infrared absorption spectra (IRS) and Raman scattering spectra (RS) of calcite-structured carbonates calculated in this work, obtained by Gaussian broadening of normal long-wavelength vibrations, are shown in Figure 2. The obtained wavenumbers of vibrations active in the IRS of calcites, together with the available experimental data, are given in Table S1; for the vibrations active in RS, they are given in Table S2 in the Supplementary materials. A good agreement was observed between the calculated vibration wavenumbers and the experimentally measured values. Thus, the average root-square deviations for eight IRS-active wavenumbers obtained by the B3LYP method for magnesite and determined experimentally in [92] and [58] do not exceed $4.0 \%$ and $3.3 \%$, respectively. There is also a good agreement with the calculated data of the authors of [93] (4.7\%) and [94] (3.5\%). The root-mean-square deviations for the wavenumbers of five vibrations active in RS, obtained by the B3LYP method in this work, are 1.3\% (1.0\%) in the experiment in [95] for magnesite (calcite), $1.5 \%(1.4 \%)$ for the experiment in [58], 1.6\% (1.1\%) for the experiment in [61], and $1.6 \%(1.7 \%)$ for the experiment in [73]. For four studied carbonates with five vibrations active in RS, in a matrix of 20 values, the deviation of the B3LYP calculation results from the experimental values [64] is $2.4 \%$.

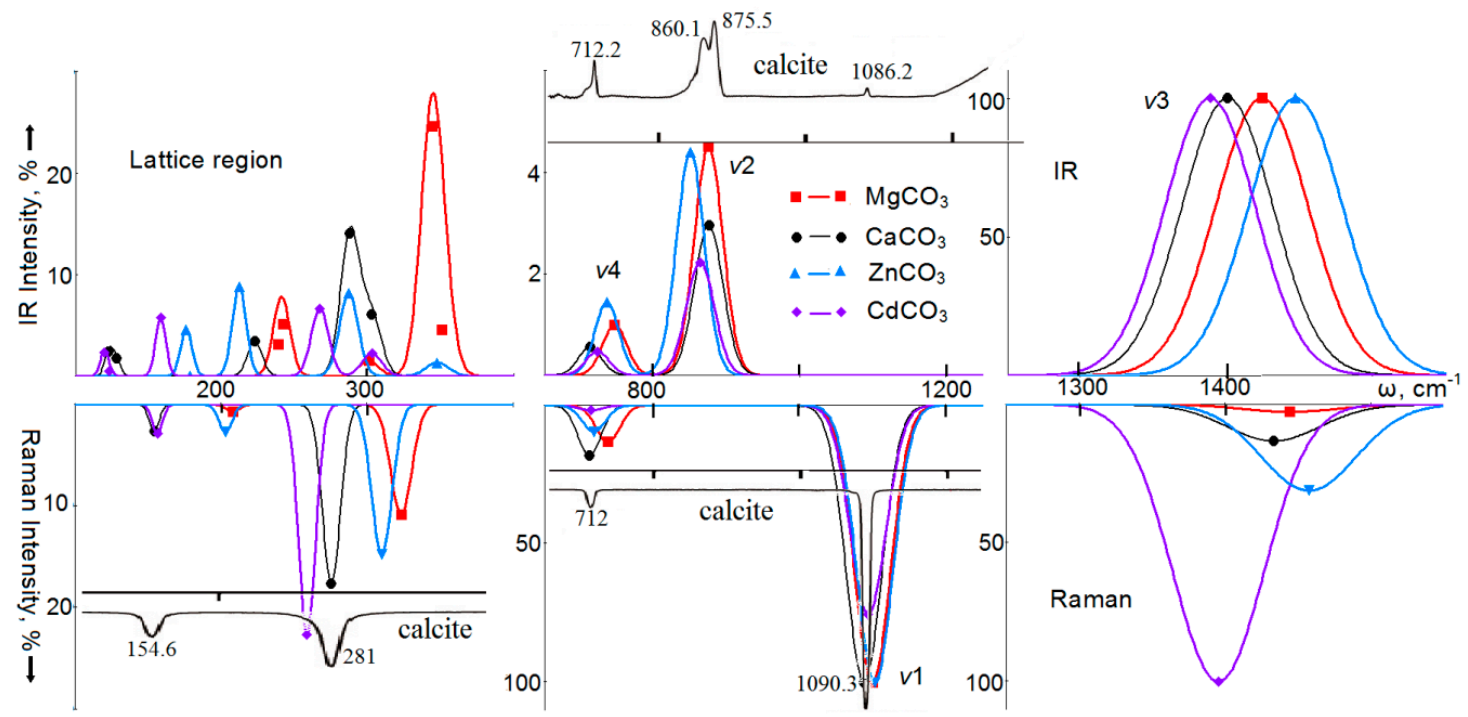

Figure 2. Calculated infrared spectra (IR) (top) and spectra of Raman light scattering (bottom) of intramolecular $v 1, v 2, v 3, v 4$, and lattice vibrations of magnesium (red, squares), calcium (black, circles), zinc (blue, triangles), and cadmium (lilac, rhombuses) carbonates with a calcite structure. For comparison, the experimental spectra of calcite are given [68].

In $\mathrm{MgCO}_{3}$, the most intense mode ( $5132 \mathrm{~km} / \mathrm{mol}$ ) in IRS corresponds to the internal vibration $v_{3}$ of $E_{\mathrm{u}}$ symmetry with the wavenumber of $1424 \mathrm{~cm}^{-1}$. Taking its intensity as $100 \%$, for the $v_{2}$ vibration with a wavenumber of $874 \mathrm{~cm}^{-1}$, we obtained $4 \%$, and for the $v_{4}\left(746 \mathrm{~cm}^{-1}\right)$ mode, even less $-0.9 \%$. In calcite, the wavenumbers corresponding to the vibrations $v_{3}, v_{2}$, and $v_{4}$ are 1400,875 , and $712 \mathrm{~cm}^{-1}$, and their intensities are $5447 \mathrm{~km} / \mathrm{mol}(100 \%), 3 \%$, and $0.5 \%$, which practically do not differ from magnesite. For $\mathrm{ZnCO}_{3}$ and $\mathrm{CdCO}_{3}$, the structures of the spectra in the high-frequency region remain similar to magnesite. Thus, for internal modes, there is a linear correlation between the change in the wavenumber and the radius of the cation $R_{\mathrm{M}}$. For $v_{4}$, it can be written in the form: $\omega_{E \mathrm{u}}\left(\mathrm{cm}^{-1}\right)=$ $812.9-98.7 \cdot R_{\mathrm{M}}(0.958)$, and with a smaller $K$ coefficient for $v_{3}: \omega_{E u}\left(\mathrm{~cm}^{-1}\right)=1546.9-154.8 \cdot R_{\mathrm{M}}(0.854)$. A good correlation $(K=0.96)$ for the calculated intensity is observed for the $v_{3}$ vibrations, where it increases with rise of atomic mass as: $I(\mathrm{~km} / \mathrm{mol})=4948+14 \mathrm{M}$, and, for the $v_{2}$ mode, it decreases with increasing radius: $I(\mathrm{~km} / \mathrm{mol})=478-326 R_{\mathrm{M}}$.

For lattice vibrations of $\mathrm{MgCO}_{3}$, the most intense ones are the $E_{\mathrm{u}}$ symmetry modes with wavenumbers of $344 \mathrm{~cm}^{-1}(25 \%), 301 \mathrm{~cm}^{-1}(2 \%)$, and $A_{2 \mathrm{u}}$ symmetry modes at $351 \mathrm{~cm}^{-1}(4 \%)$, 
$242 \mathrm{~cm}^{-1}(5 \%)$. For $\mathrm{CaCO}_{3}$, the lattice modes are shifted to the low-wavenumber region, and their intensities decrease. In the region of lattice vibrations of $\mathrm{ZnCO}_{3}$, the most intense modes will be $E_{\mathrm{u}}$ symmetry with wavenumbers of $287 \mathrm{~cm}^{-1}, 212 \mathrm{~cm}^{-1}$, and only then with $A_{2 \mathrm{u}}$ symmetry: $348 \mathrm{~cm}^{-1}, 176 \mathrm{~cm}^{-1}$. In $\mathrm{CdCO}_{3}$, this trend continues. Thus, for translation modes of $E_{\mathrm{u}}$ symmetry, a dependence on the cation mass is observed: $\omega\left(\mathrm{cm}^{-1}\right)=306.0-1.37 \cdot \mathrm{M}(0.915)$. For the rest of the lattice modes, the best linear dependence was established for the cation radius: for rotational ones: $\omega_{\mathrm{Eu}}\left(\mathrm{cm}^{-1}\right)=466.5-353.1 \cdot R_{\mathrm{M}}(0.91), \omega_{A 2 \mathrm{u}}\left(\mathrm{cm}^{-1}\right)=463.2-348.5 \cdot R_{\mathrm{M}}(0.884$, and for translational modes: $\omega_{A 2 u}\left(\mathrm{~cm}^{-1}\right)=484.7-186.3 \cdot R_{\mathrm{M}}(0.991)$.

In RS, the intense line (taken as $100 \%$ ) in Figure 2 is due to vibrations of the $v_{1}$ type, and falls on $1099 \mathrm{~cm}^{-1}$ in $\mathrm{MgCO}_{3}$, and $1087 \mathrm{~cm}^{-1}$ in calcite. This mode has a significant polarization dependence [89]: the $x x$ and $y y$ components are ten times larger than the $z z$ component. Internal vibrations of $v_{4}$ type also have a noticeable intensity: for magnesite-with a wavenumber of $737 \mathrm{~cm}^{-1}$, for calcite- $711 \mathrm{~cm}^{-1}$, and also for $v_{3}$ type: $1444 \mathrm{~cm}^{-1}$ and $1433 \mathrm{~cm}^{-1}$, respectively. In carbonates of relatively heavy metals zinc and cadmium, the positions of the maxima of the $v_{4}$ and $v_{1}$ bands are practically preserved $\left(\omega_{E g}\left(\mathrm{~cm}^{-1}\right)=783.3-72.9 \cdot R_{\mathrm{M}}(0.906), \omega_{\mathrm{A} 1 \mathrm{~g}}\left(\mathrm{~cm}^{-1}\right)=1138.0-49.2 \cdot R_{\mathrm{M}}(0.906)\right)$, whereas for the $v_{3}$ region the changes are significant. This is due to the fact that the intensity of this mode increases linearly with an increase in the atomic mass of the metal cation: $I_{v 3}(\%)=-29.9+1.1 \cdot \mathrm{M}(0.987)$. For $\mathrm{CdCO}_{3}$, the $v_{3}$ vibration becomes the most intense in RS and has pronounced $x z$ and $y z$ polarizations.

For lattice vibrations, the most intense vibration in the RS spectrum has the $E_{\mathrm{g}}$ symmetry, and its wavenumbers in $\mathrm{MgCO}_{3}$ are $323 \mathrm{~cm}^{-1}$ (intensity $\left.11 \%\right), \mathrm{ZnCO}_{3} 310 \mathrm{~cm}^{-1}(15 \%), \mathrm{CdCO}_{3} 258 \mathrm{~cm}^{-1}(23 \%)$, and $\mathrm{CaCO}_{3} 275 \mathrm{~cm}^{-1}(18 \%)$. Thus, for the lattice translational vibration, there is a linear dependence of the form $\omega\left(\mathrm{cm}^{-1}\right)=361.0-210.6 \cdot R_{\mathrm{M}}(0.992)$, and for rotational, $\omega\left(\mathrm{cm}^{-1}\right)=449.0-185.5 \cdot R_{\mathrm{M}}(0.912)$. Since there is a good linear relationship between $R_{\mathrm{M}-\mathrm{O}}$ and the radius of the $R_{\mathrm{M}}$ cation, the above formulas can easily be rewritten for distances as well. The above formulas allow predicting the wavenumber values for other carbonates; thus, for the lattice modes $E_{g}(\mathrm{~T}), E_{g}(\mathrm{~L})$, internal $v_{4}$ and $v_{1}$, the wavenumbers predicted by the formulas for $\mathrm{MnCO}_{3}$ are 186, 296, 723, and $1097 \mathrm{~cm}^{-1}$, and for $\mathrm{CoCO}_{3}$, they are 204, 311, 729, and $1101 \mathrm{~cm}^{-1}$. The experimental values for rhodochrosite are 184, 290, 719 , and $1086 \mathrm{~cm}^{-1}$ [62]; for spherocobaltite, they are 194, 302, 725, and $1090 \mathrm{~cm}^{-1}$ [34].

\section{Vibrational Spectra of Crystals with a Dolomite Structure}

The IRS and RS of carbonates with the dolomite structure are given in Figure 3, and Tables S3 and S4 of the accompanying materials show the wavenumbers of normal long-wave vibrations of crystals with the dolomite and norsethite structures, calculated by the B3LYP method and measured experimentally. The examination of these tables shows that there is a satisfactory agreement between the wavenumbers of lattice [69] and internal [61] vibrations of natural dolomite calculated and measured in IRS. The root-mean-square deviation is 8.7 and $1.0 \%$, respectively. For the wavenumbers of vibrations active in RS, the root-mean-square deviation of the results of this calculation from the experimental values is $1.4 \%$. In crystals with a dolomite structure, the picture of theoretical spectra does not differ significantly from the calcite spectra. In IRS CaMg $\left(\mathrm{CO}_{3}\right)_{2}$, the most intense mode $(5318 \mathrm{~km} / \mathrm{mol}, 100 \%)$ is the $v_{3}$ mode at $1416 \mathrm{~cm}^{-1}$. The internal vibration $v_{2}$ with a wavenumber of $877 \mathrm{~cm}^{-1}$ has an intensity of $3.5 \%$, and for vibration $v_{4}$ at $727 \mathrm{~cm}^{-1}$, the intensity is close to $1 \%$. Unlike calcite, the vibration $v_{1}$ of the $A_{\mathrm{u}}$ symmetry is allowed by symmetry; however, its intensity is practically zero. The most intense $(19 \%)$ in the region of lattice vibrations is the $E_{\mathbf{u}}$ symmetry mode with a wavenumber of $337 \mathrm{~cm}^{-1}$. Modes of the same symmetry, but with a much lower intensity, appear at $257(2.5 \%)$ and $167 \mathrm{~cm}^{-1}(4 \%)$. 


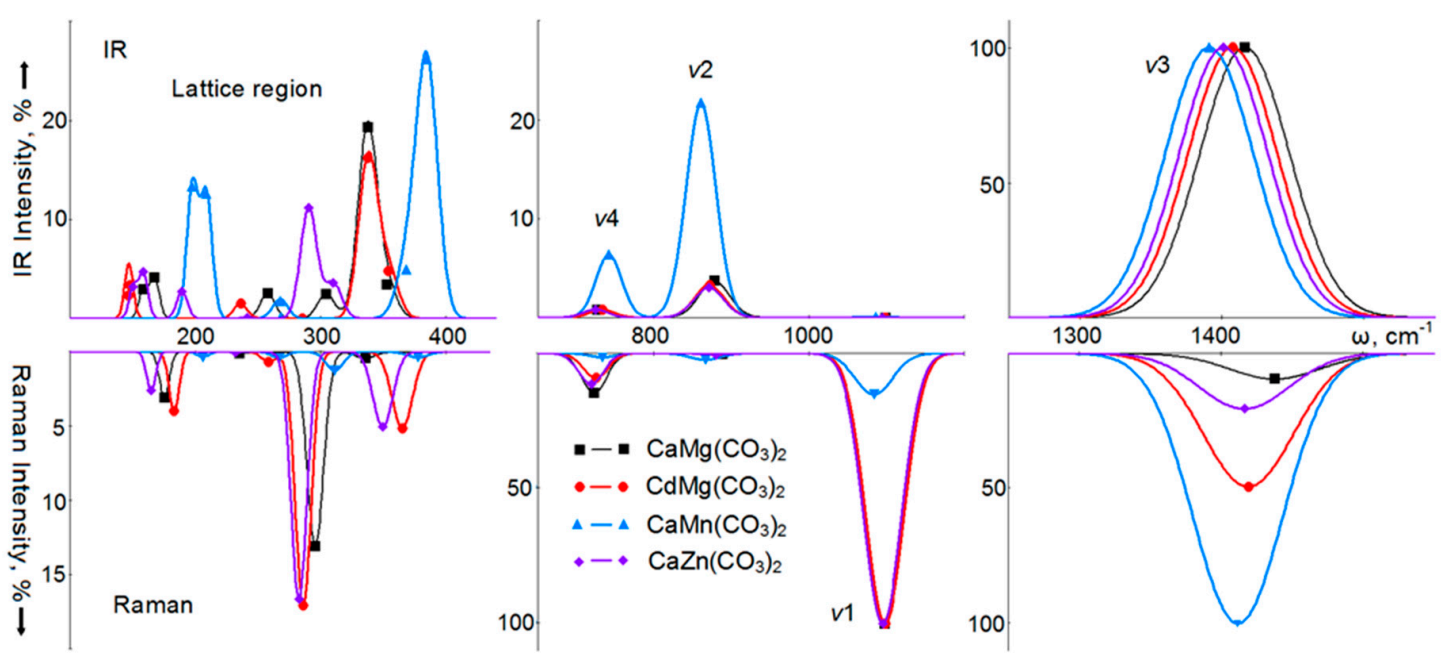

Figure 3. Calculated infrared spectra (IR) (top) and Raman spectra (bottom) of intramolecular $v 1, v 2$, $\vee 3, v 4$, and lattice vibrations of double calcium-magnesium (black, squares), cadmium-magnesium (red, circles), calcium-manganese (blue, triangles), and calcium-zinc carbonates (lilac, rhombuses) with a dolomite structure.

In $\mathrm{CdMg}\left(\mathrm{CO}_{3}\right)_{2}$, the most intense $(5788 \mathrm{~km} / \mathrm{mol}, 100 \%)$ vibration will be $v_{3}$ with a wavenumber of $1407 \mathrm{~cm}^{-1}$, and for lattice vibration with a wavenumber of $338 \mathrm{~cm}^{-1}$, the intensity is $16 \%$. A similar picture is observed in $\mathrm{CaZn}\left(\mathrm{CO}_{3}\right)_{2}$, where the intensity of the $v_{3}$ vibration is $5928 \mathrm{~km} / \mathrm{mol}(100 \%)$, and the intensities of two lattice vibrations with wavenumbers of 290 and $310 \mathrm{~cm}^{-1}$ are $11 \%$ and $3.5 \%$, respectively. The situation is different in $\mathrm{CaMn}\left(\mathrm{CO}_{3}\right)_{2}$, where the intensity of the $v_{3}$ mode is much lower- $1121 \mathrm{~km} / \mathrm{mol}(100 \%)$, and against its background, the relative intensities of other $v_{2}$ and $v_{4}$ vibrations increased to 22 and $6 \%$, respectively.

The RS of dolomite will be dominated by a fully $v_{1}$ symmetric vibration with a wavenumber of $1097 \mathrm{~cm}^{-1}$. Its full intensity is taken as $100 \%$. Then, the intensities of the $v_{4}, v_{2}$, and $v_{3}$ modes will be $15 \%, 0.2 \%$ and $9 \%$, respectively. In the region of lattice vibrations, the most intense are the $E_{\mathrm{g}}$ symmetry modes with wavenumbers of $296 \mathrm{~cm}^{-1}(13 \%)$ and $175 \mathrm{~cm}^{-1}(3 \%)$. In $\mathrm{CdMg}\left(\mathrm{CO}_{3}\right)_{2}$, the $v_{1}$ mode does not change in wavenumber and remains most intense. The wavenumber of the $v_{3}$ mode decreases, but its intensity sharply increases to $49 \%$. In $\left.\mathrm{CaMn}_{(\mathrm{CO}}\right)_{2}$, the intensity of the $v_{3}$ mode becomes maximum (taken as $100 \%$ ), while for the $v_{1}$ vibration it is only $15 \%$. Thus, as for IRS, the binary carbonate $\mathrm{CaMn}\left(\mathrm{CO}_{3}\right)_{2}$ differs from other crystalline dolomites in the parameters of its vibrational spectra.

In IRS of the $\mathrm{BaMg}\left(\mathrm{CO}_{3}\right)_{2}$ crystal (Figure 4 ) in the region of intramolecular vibrations, the most intense $(5194 \mathrm{~km} / \mathrm{mol})$ vibration will be $v_{3}$ with a wavenumber of $1439 \mathrm{~cm}^{-1}$. Against this background, the $v_{2}$ vibration with a wavenumber of $878 \mathrm{~cm}^{-1}$ and the intensity of $3 \%$ is almost imperceptible, moreover, the $v_{4}$ vibrations $\left(694 \mathrm{~cm}^{-1}, 0.5 \%\right)$ and $v_{1}$ allowed here $\left(1125 \mathrm{~cm}^{-1}, 0.2 \%\right)$ practically do not appear. In the region of lattice vibrations, vibrations of $E_{\mathrm{u}}$ symmetry with wavenumbers of 315,200 , and $106 \mathrm{~cm}^{-1}$ stand out in intensity, while less intense vibrations of $A_{2 \mathrm{u}}$ symmetry have wavenumbers of 347 and $115 \mathrm{~cm}^{-1}$. The first of these less intense vibrations corresponds to the displacements of magnesium atoms in antiphase with the anions, and the second corresponds to the displacements of barium atoms. Magnesium atoms are also involved in the formation of this mode, and they shift synchronously with the anion. In $\mathrm{RS}$ of $\mathrm{BaMg}\left(\mathrm{CO}_{3}\right)_{2}$, vibrations of anion atoms will also dominate: $v_{1}$ with a wavenumber of $1126 \mathrm{~cm}^{-1}$ (its intensity is taken as $\left.100 \%\right), v_{2}$ of the same symmetry and intensity of $3 \%$, as well as doubly degenerated $v_{4}\left(697 \mathrm{~cm}^{-1}\right)$ and $v_{3}\left(1444 \mathrm{~cm}^{-1}\right)$ with intensities of $21 \%$ and $3 \%$, respectively. For lattice vibrations, the $A_{1 \mathrm{~g}}$ symmetry mode with a wavenumber of $284 \mathrm{~cm}^{-1}$ and $E_{\mathrm{g}}$ symmetry modes with wavenumbers of 108 and $254 \mathrm{~cm}^{-1}$ will be noticeable, of which the first is rotational, and the second is translational vibration. 


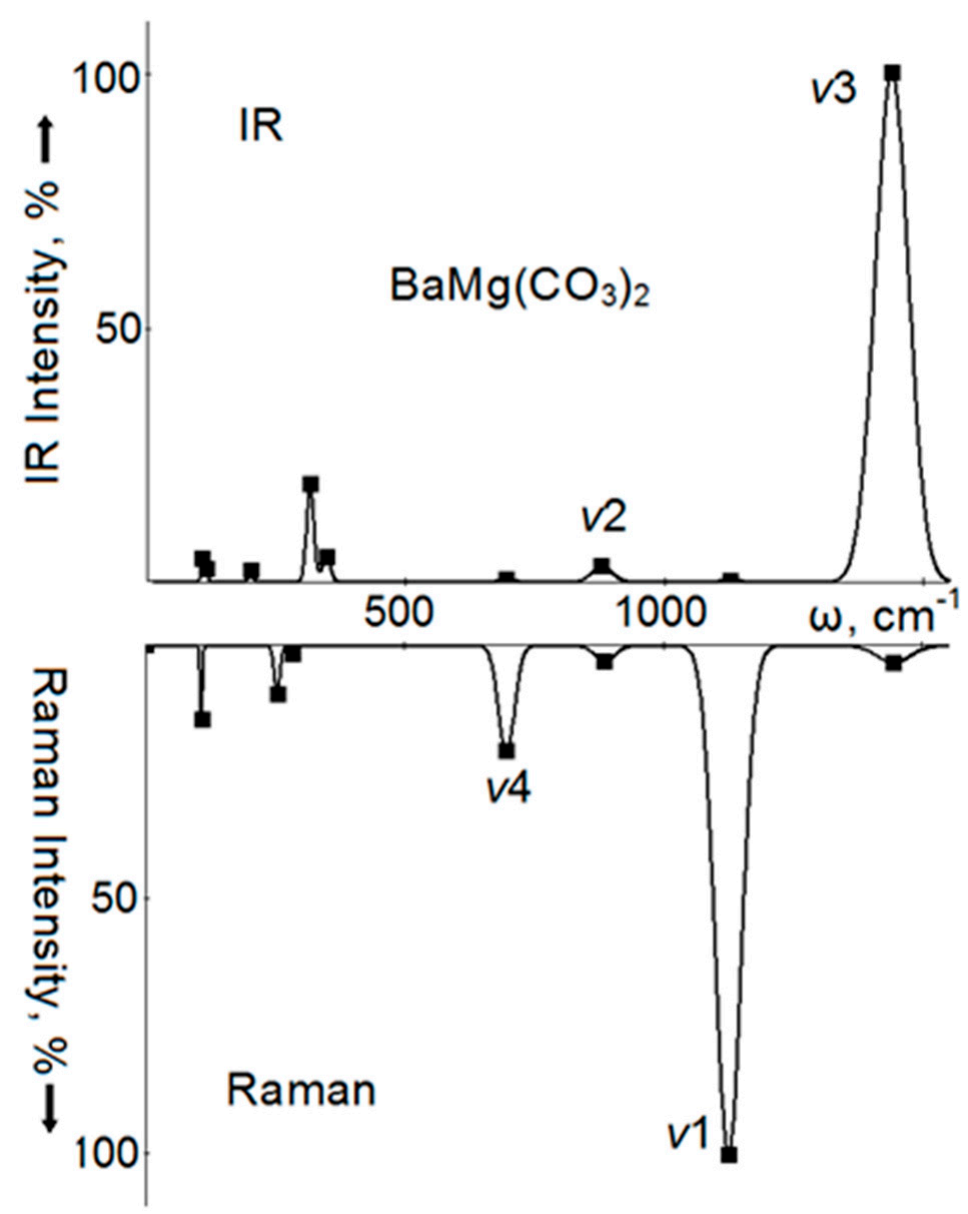

Figure 4. Calculated infrared spectrum (IR) (top) and Raman spectrum (bottom) of intramolecular $v 1$, $v 2, v 3, v 4$, and lattice vibrations of double barium-magnesium carbonate in a norsesite-type structure. The solid line is the Gaussian broadening of the frequencies of long-wave oscillations (squares).

Let us establish ordinary dependences for the entire class of trigonal crystals. For the lowestwavenumber lattice translational vibration in IRS $\omega_{\mathrm{Eu}}\left(\mathrm{cm}^{-1}\right)=379.0-244.3 \cdot R_{\mathrm{M}}(0.794)$; for $\mathrm{RS}, \omega_{\mathrm{Eg}}\left(\mathrm{cm}^{-1}\right)$ $=367.3-216.2 \cdot R_{\mathrm{M}}(0.896)$, and $\omega_{\mathrm{Eg}}\left(\mathrm{cm}^{-1}\right)=413.1-39.6 \cdot R_{\mathrm{M}}(0.813)$. Using the first formula, we obtain for ankerite $\left(\mathrm{CaFe}\left(\mathrm{CO}_{3}\right)_{2}\right) 164 \mathrm{~cm}^{-1}$ (in experiment, $166 \mathrm{~cm}^{-1}$ [72]), kutnogorite $\mathrm{Ca}_{0.78} \mathrm{Mn}_{1.13}\left(\mathrm{CO}_{3}\right)_{2} 159 \mathrm{~cm}^{-1}$ $\left(153 \mathrm{~cm}^{-1}\right)$. For lattice vibrations active in RS, the formulas give estimated values for rhodochrosite $\left(\mathrm{MnCO}_{3}\right)$ 188, $297 \mathrm{~cm}^{-1}$. The experimental values are 185 and $290 \mathrm{~cm}^{-1}$ [73].

\section{Vibrational Spectra of Crystals with Aragonite Structure}

The calculated spectra of infrared absorption and Raman light scattering of calcium, strontium, lead, and barium carbonates with aragonite structure are shown in Figure 5. The wavenumbers of normal long-wave vibrations of crystals with the aragonite structure calculated by the B3LYP method, together with the available experimental and theoretical data, are summarized in Tables S5-S8 of the Supplementary Materials. The comparison of wavenumbers calculated by the B3LYP method with the experimental values shows that the root-mean-square deviation for four $v_{1}-v_{4}$ wavenumbers in four carbonates is, according to [68], $1.5 \%$ for IRS; $0.8 \%$ for RS; for IRS [55] $-2.0 \%$, and for RS [57] $-0.9 \%$. 


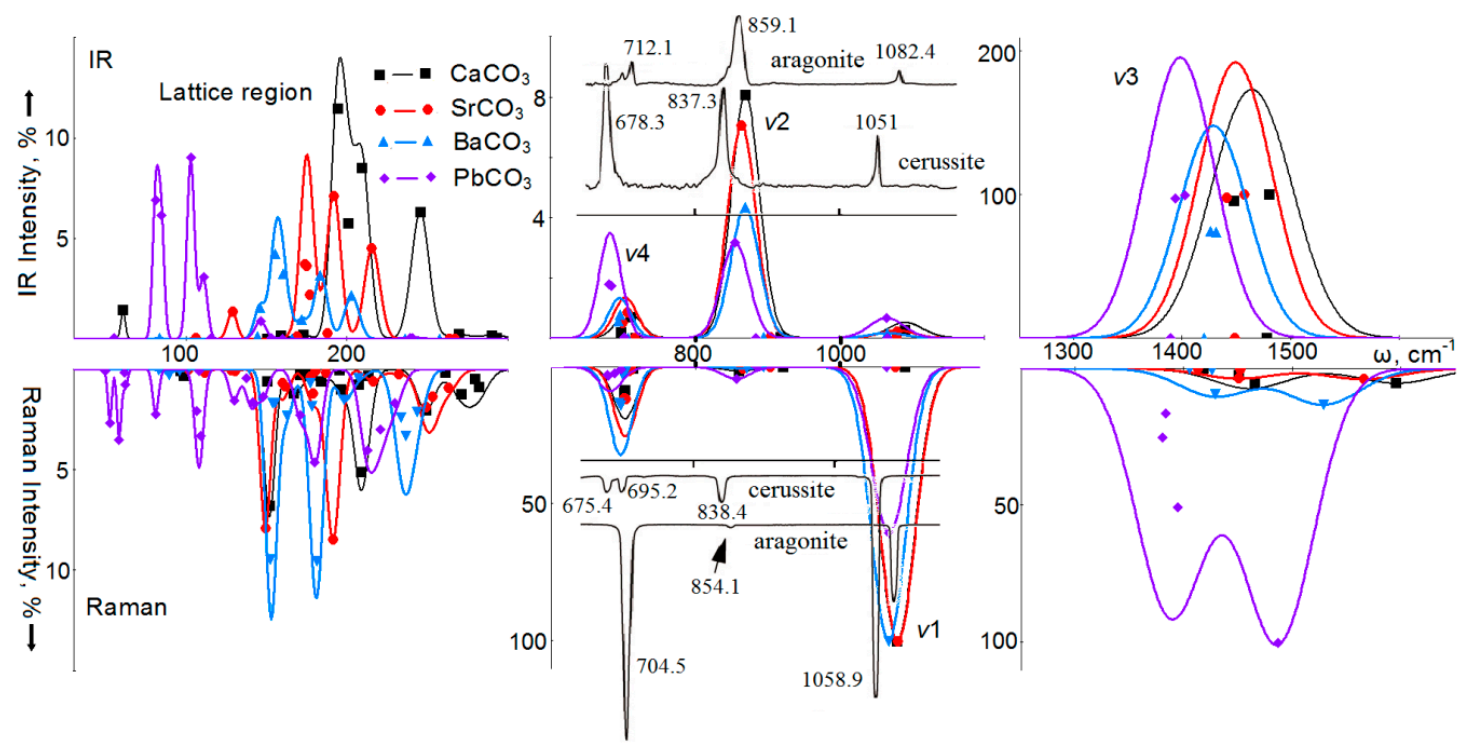

Figure 5. Calculated infrared spectra (IR) (top) and Raman spectra (bottom) of intramolecular v1, v2, $\vee 3, v 4$, and lattice vibrations of calcium (black, squares), strontium (red, circles), barium (blue, triangles), lead carbonates (lilac, rhombuses) with aragonite structure. For comparison, the experimental spectra of aragonite and cerussite are given [68] (Reproduced with permission from [68]; Copyright Springer Nature, 2020).

In the IRS of aragonite, the most intense vibrations are of the $v_{3}$ type with the $B_{2 u}, B_{3 u}$ symmetry, wavenumbers of 1448 and $1480 \mathrm{~cm}^{-1}$ and intensities of 4523 and $4727 \mathrm{~km} / \mathrm{mol}$. In Figure 4, they correspond to a broad intense band with the maximum at $1462 \mathrm{~cm}^{-1}\left(1461 \mathrm{~cm}^{-1}\right.$ in [68]). For convenience of comparison, the intensity of vibration of $B_{3 u}$ symmetry is taken as $100 \%$. In $\mathrm{SrCO}_{3}$, the maximum intensity of the $B_{3 \mathrm{u}}$ mode at $4757 \mathrm{~km} / \mathrm{mol}$ is taken as $100 \%$, in $\mathrm{BaCO}_{3}$, the $B_{2 \mathrm{u}}$ symmetry modes at $4953 \mathrm{~km} / \mathrm{mol}$, and in $\mathrm{PbCO}_{3}: 6241 \mathrm{~km} / \mathrm{mol}$. Thus, the intensity $v_{3}$ increases with the atomic mass of the metal, and the position of the maximum in the series changes according to the law: $\omega\left(\mathrm{cm}^{-1}\right)=1480.2-0.365 \cdot \mathrm{M}\left(\mathrm{cm}^{-1}\right)$ with a correlation coefficient of 0.991 .

Unlike calcite, in the infrared spectra of aragonite, the vibration of the $v_{1}$ type will be active due to the modes of symmetry $B_{3 u}, B_{1 u}$. In the spectrum shown in Figure 4 , they correspond to a weak $(0.2 \%)$ band with a maximum at $1090 \mathrm{~cm}^{-1}$, the wavenumber of which shifts towards lower values with increasing atomic mass: $\omega\left(\mathrm{cm}^{-1}\right)=1090.6-0.127 \cdot \mathrm{M}$. The intensity of vibrations of the $v_{2}$ type of $B_{1 \mathrm{u}}$ symmetry is much higher than that of $v_{1}$ vibrations, it decreases with an increase in the atomic mass of the metal, and its wavenumber practically does not change: $\omega\left(\mathrm{cm}^{-1}\right)=893.3-0.065 \cdot \mathrm{M}$. In the experimental spectra, this dependence has the form: $\omega\left(\mathrm{cm}^{-1}\right)=866.2-0.123 \cdot \mathrm{M}$. Vibrations of the $v_{4}$ type in $\mathrm{CaCO}_{3}$ and $\mathrm{SrCO}_{3}$ correspond to the modes of symmetries $B_{3 \mathrm{u}}, B_{2 \mathrm{u}}$ with distances between wavenumbers of 13 and $6 \mathrm{~cm}^{-1}$. In $\mathrm{BaCO}_{3}$ and $\mathrm{PbCO}_{3}$, the distances between wavenumbers decrease to 2 and $3 \mathrm{~cm}^{-1}$. This behavior of vibrational modes of the $v_{4}$ type is consistent with experimental data [68], where it was found that two peaks are observed in aragonite $\left(\mathrm{CaCO}_{3}\right)$ and strontianite $\left(\mathrm{SrCO}_{3}\right)$, and only one for cerussite $\left(\mathrm{PbCO}_{3}\right)$ and witherite $\left(\mathrm{BaCO}_{3}\right)$. There is a good ordinary dependence of the peak position on the atomic mass of the metal: in the experiment it is $\omega\left(\mathrm{cm}^{-1}\right)=707.5-0.128 \cdot \mathrm{M}$, and in the calculation: $\omega\left(\mathrm{cm}^{-1}\right)=715.4-0.119 \cdot \mathrm{M}$, with the correlation coefficients 0.944 and 0.977 , respectively.

In the Raman spectrum of aragonite $\left(\mathrm{CaCO}_{3}\right), v_{1}$ vibration of $A_{\mathrm{g}}$ symmetry with a wavenumber of $1078 \mathrm{~cm}^{-1}$ is the most intense (taken as $100 \%$ ). Vibrations $v_{4}$ of the $A_{\mathrm{g}}$ and $B_{1 \mathrm{~g}}$ symmetries with intensities of $9 \%$ each are also noticeable, which form the maximum in the spectrum shown in Figure 5 at $702 \mathrm{~cm}^{-1}$. In $\mathrm{BaCO}_{3}$, the $v_{1}$ vibration maximum shifts to $696 \mathrm{~cm}^{-1}$, and its intensity increases. In addition, the width of this peak increases. Oscillations of the $v_{3}$ type in $\mathrm{CaCO}_{3}$ have $B_{3 \mathrm{~g}}$ $\left(1465 \mathrm{~cm}^{-1}\right)$ and $B_{2 \mathrm{~g}}\left(1595 \mathrm{~cm}^{-1}\right)$ symmetries, and an intensity of $5 \%$. In $\mathrm{SrCO}_{3}$, these are vibrations 
at wavenumbers of 1450 and $1565 \mathrm{~cm}^{-1}$ with intensities of $4 \%$. In $\mathrm{BaCO}_{3}$, they shift to lower values of 1429 and $1528 \mathrm{~cm}^{-1}$, and the intensities increase to 9 and $13 \%$. Oscillations of the $B_{2 \mathrm{~g}}$ symmetry correspond to the displacements of atoms to the $\mathrm{C}-\mathrm{O}$ bonds along the $b$ axis, whereas $B_{3 \mathrm{~g}}$-along the $a$ axis, perpendicular to the layers of anions and cations.

The Raman spectrum of $\mathrm{PbCO}_{3}$ differs from the spectra of other carbonates with the aragonite structure. Here, the most intense (taken as $100 \%$ ) is the vibration of the $v_{3}$ type of $B_{2 \mathrm{~g}}$ symmetry with a wavenumber of $1486 \mathrm{~cm}^{-1}$ [68]. Three other vibrations of this type have $B_{3 \mathrm{~g}}, A_{\mathrm{g}}, B_{1 \mathrm{~g}}$ symmetries, similar wavenumbers of 1394,1383 and $1380 \mathrm{~cm}^{-1}$ and intensities of $50 \%, 16 \%$, and $25 \%$, respectively. They form a second maximum in RS at $1388 \mathrm{~cm}^{-1}$. The $v_{1}$-type vibration with a wavenumber of $1067 \mathrm{~cm}^{-1}$ has an intensity of $61 \%$. Modes of the same $A_{\mathrm{g}}$ symmetry are also dominant in the formation of the $v_{2}$ band, the position of which in aragonites obeys the law: $\omega\left(\mathrm{cm}^{-1}\right)=895.6-0.117 \cdot \mathrm{M}$ with a high correlation coefficient of 0.977 .

In the IRS of aragonite, in the region of lattice vibrations, there is a maximum at $245 \mathrm{~cm}^{-1}$, formed by the $B_{3 \mathrm{u}}$ symmetry mode with an intensity of $13 \%$, and the main maximum with an intensity of $23 \%$ at $194 \mathrm{~cm}^{-1}\left(B_{2 u}\right.$ symmetry). For $\mathrm{SrCO}_{3}$, four peaks are observed at 129, 175, 192 and $215 \mathrm{~cm}^{-1}$ with intensities of 3,18,15 and $9 \%$, while in $\mathrm{BaCO}_{3}$ the intense band is at $157 \mathrm{~cm}^{-1}\left(B_{1 \mathrm{u}}\right.$ and $\left.B_{3 \mathrm{u}}\right)$ with a low-wavenumber band at $146 \mathrm{~cm}^{-1}$, and high-wavenumber at $171 \mathrm{~cm}^{-1}$ shoulders. In $\mathrm{PbCO}_{3}$, the main features of the spectrum are shifted to the low-wavenumber region. There are two main peaks at $82 \mathrm{~cm}^{-1}$ with an intensity of $17 \%$, and a peak at $103 \mathrm{~cm}^{-1}$ and an intensity of $18 \%$. This structure of the IRS in the lattice region is consistent with the results of measurements [72], where it was found that the broad band at $263 \mathrm{~cm}^{-1}$ in the structure of aragonite shifts to longer wavelengths with an increase in the atomic number of the metal: up to $227 \mathrm{~cm}^{-1}$ in strontianite, then up to $205 \mathrm{~cm}^{-1}$ in witherite, and, finally, up to $136 \mathrm{~cm}^{-1}$ in cerussite.

For lattice vibrations of aragonite in RS, there will be three main bands with maxima at $152 \mathrm{~cm}^{-1}$, $209 \mathrm{~cm}^{-1}$ and 250, $276 \mathrm{~cm}^{-1}$. There is a good agreement between the calculated and experimental data [68]. In $\mathrm{SrCO}_{3}$, there are two intense bands with maxima at 150 and $191 \mathrm{~cm}^{-1}$, formed by the modes of symmetries $B_{3 g}, B_{2 g}$, and a weak band at $252 \mathrm{~cm}^{-1}$. In the $\mathrm{BaCO}_{3}$ spectrum, the maximum of the first band is at $153 \mathrm{~cm}^{-1}$, the second at $181 \mathrm{~cm}^{-1}$ with a shoulder at $198 \mathrm{~cm}^{-1}$, and the third at $237 \mathrm{~cm}^{-1}$. The second maximum is formed by modes with $B_{2 \mathrm{~g}}$ symmetry with pronounced $y z$ polarization. The spectrum of $\mathrm{PbCO}_{3}$ contains a large number of bands of low intensity, not exceeding $6 \%$.

In [68], it was found that RS and IRS confirm the general trend that each of the internal modes is shifted to lower wavenumbers in the following order: aragonite $\rightarrow$ strontianite $\rightarrow$ witherite $\rightarrow$ cerussite. The coefficients of linear interpolation of the wavenumbers of intramolecular $\left(v_{4}, v_{1}, v_{3}\right)$ vibrations active in RS for carbonates with the aragonite structure, obtained from experimental data [68] and theoretical calculations using the B3LYP method are summarized in Table 2. In the calculations, each type of vibration was determined as the average of the individual modes, which are shown in Table S9. For lattice vibrations, similar linear dependences are also obtained, as recorded in Table S10.

Table 2. Linear interpolation coefficients of the wavenumbers of intramolecular $\left(v_{4}, v_{1}, v_{3}\right)$ vibrations of the $\mathrm{M}$ cation mass for carbonates with aragonite structure, active in RS, obtained from experimental data [68] and theoretical calculations by the B3LYP method. The correlation coefficient is shown in brackets.

\begin{tabular}{ccccc}
\hline Method & $\boldsymbol{v}_{\mathbf{4}}$ & $\boldsymbol{v}_{\mathbf{1}}$ & $\boldsymbol{v}_{\mathbf{3}}$ & $\boldsymbol{v}_{\mathbf{3}}$ \\
\hline Experiment [68] & $713.2-0.173 \cdot \mathrm{M}(0.986)$ & $1090.1-0.17 \cdot \mathrm{M}(0.919)$ & $1495.3-0.588 \cdot \mathrm{M}(0.989)$ & $1597.2-0.582 \cdot \mathrm{M}(0.99)$ \\
B3LYP & $714.3-0.128 \cdot \mathrm{M}(0.933)$ & $1087.059-0.116 \cdot \mathrm{M}(0.894)$ & $1486.0-0.426 \cdot \mathrm{M}(0.992)$ & $1619.0-0.638 \cdot \mathrm{M}(0.998)$ \\
\hline
\end{tabular}

As a check of the obtained formulas, we will use the available data [49], where the Raman spectra of $\left(\mathrm{CaCO}_{3}\right) \times 1\left(\mathrm{SrCO}_{3}\right) \times 2\left(\mathrm{BaCO}_{3}\right) \times 3$ solid solutions were measured. Thus, in the spectrum of the composition 0.34:0.33:0.33, wavenumbers of 1452, 1086, 711, 273, 192, $155 \mathrm{~cm}^{-1}$ were observed. Calculation according to the formulas of Tables S8 and S9 gives: 1466, 1077, 703, 262, 183, and $158 \mathrm{~cm}^{-1}$, 
that is, the root mean square deviation of the calculated and experimentally determined wavenumbers is about $2.7 \%$.

\section{Conclusions}

In this work, the Hartree-Fock theory and the electron density functional in the form of a hybrid B3LYP functional in the basis of a linear combination of atomic orbitals by means of the CRYSTAL17 program code are used to calculate the structure and normal long-wavelength vibrations of $\mathrm{MgCO}_{3}, \mathrm{CaCO}_{3}, \mathrm{ZnCO}_{3}, \mathrm{CdCO}_{3}$ in the structure of calcite, $\mathrm{CaMg}\left(\mathrm{CO}_{3}\right)_{2}, \mathrm{CdMg}\left(\mathrm{CO}_{3}\right)_{2}, \mathrm{CaMn}\left(\mathrm{CO}_{3}\right)_{2}$, $\mathrm{CaZn}\left(\mathrm{CO}_{3}\right)_{2}$-in the structure of dolomite, $\mathrm{BaMg}\left(\mathrm{CO}_{3}\right)_{2}$-in the structure of the norsethite type, $\mathrm{CaCO}_{3}, \mathrm{SrCO}_{3}, \mathrm{BaCO}_{3}, \mathrm{PbCO}_{3}$-in the structure of aragonite. The analysis of the calculated results and their comparison with the available experimental data shows that the wavenumbers and intensities of individual vibrational modes obey the ordinary laws. For the calcite family, the intramolecular modes of the $v_{2}$ and $v_{3}$ types that are active in IRS correlate with the cation radius $\omega\left(\mathrm{cm}^{-1}\right)=812.9-98.7 \cdot R_{\mathrm{M}}$, and $\omega\left(\mathrm{cm}^{-1}\right)=1546.9-154.8 \cdot R_{\mathrm{M}}$ with correlation coefficients of 0.958 and 0.854 . Vibration of the $v_{4}$ type is active in RS, where the dependence of its wavenumber on the radius of the metal cation has the form $\omega\left(\mathrm{cm}^{-1}\right)=783.3-72.9 \cdot R_{\mathrm{M}}$, and for the most intense $v_{1}: \omega\left(\mathrm{cm}^{-1}\right)=1138.0-42.9 \cdot R_{\mathrm{M}}$, with coefficients of correlation 0.906 . For the entire class of trigonal crystals (calcite, dolomite, norsethite), the dependence of low- wavenumber lattice vibrations has the form for $E_{\mathrm{u}}$ symmetry: $E_{\mathrm{u}}: \omega\left(\mathrm{cm}^{-1}\right)=379.0-243.3 \cdot R_{\mathrm{M}}$, and $E_{\mathrm{g}}: \omega\left(\mathrm{cm}^{-1}\right)=367.3-216.2 \cdot R_{\mathrm{M}}$, $\omega\left(\mathrm{cm}^{-1}\right)=413.1-139.6 \cdot R_{\mathrm{M}}$. For carbonates with aragonite structure for the calculated wavenumbers $v_{4}, v_{2}, v_{1}, v_{3}$, linear dependences with high correlation coefficients are obtained for the atomic mass: $\omega\left(\mathrm{cm}^{-1}\right)=714.3-0.128 \cdot \mathrm{M} ; \omega\left(\mathrm{cm}^{-1}\right)=895.6-0.117 \cdot \mathrm{M} ; \omega\left(\mathrm{cm}^{-1}\right)=1087.1-0.116 \cdot \mathrm{M}$; $\omega\left(\mathrm{cm}^{-1}\right)=1619.0-0.638 \cdot \mathrm{M}$, and for IRS: $\omega\left(\mathrm{cm}^{-1}\right)=715.4--0.119 \cdot \mathrm{M}^{\prime} ; \omega\left(\mathrm{cm}^{-1}\right)=893.3-0.065 \cdot \mathrm{M}$; $\omega\left(\mathrm{cm}^{-1}\right)=1090.6-0.127 \cdot \mathrm{M} ; \omega\left(\mathrm{cm}^{-1}\right)=1480.2-0.365 \cdot \mathrm{M}$. For trigonal and orthorhombic carbonates, linear dependences of metal substitution were established for the radius of the RM cation (the distance between the metal and oxygen $\left.R_{\mathrm{M}-\mathrm{O}}\right)$ only for the infrared in-plane bending mode $v_{4}: \omega\left(\mathrm{cm}^{-1}\right)=$ $786.2-65.88 \cdot R_{\mathrm{M}}\left(\omega\left(\mathrm{cm}^{-1}\right)=881.0-67.13 \cdot R_{\mathrm{M}-\mathrm{O}}\right)$, and Raman in-plane asymmetric stretching mode $v_{4}: \omega\left(\mathrm{cm}^{-1}\right)=768.5-53.24 \cdot R_{\mathrm{M}}\left(\omega\left(\mathrm{cm}^{-1}\right)=844.2-53.83 \cdot R_{\mathrm{M}-\mathrm{O}}\right)$, with a correlation coefficient of $0.87(0.91)$. For the rest of the modes, it was not possible to obtain linear dependences with high correlation coefficients.

Thus, ab initio predictions, with a relatively low computational capacity, can reproduce the full vibrational spectra of crystalline compounds of material science interest, and, on the basis of ordinary spectral dependences, predict their features for solid crystalline solutions. The obtained quantitative dependences of the characteristics of vibrational modes can be used in non-contact non-destructive diagnostics of carbonates by optical methods.

Supplementary Materials: The following are available online at http://www.mdpi.com/2079-4991/10/11/2275/s1, Table S1: Wavenumbers $\left(\mathrm{cm}^{-1}\right)$ of lattice, translational $(\mathrm{T})$, rotational $(\mathrm{L})$ and internal mode vibrations active in IR spectra (IR), obtained in this work by the B3LYP method, measured experimentally (Exp.) and calculated (Theor.) for carbonates with calcite structure, Table S2: Wavenumbers $\left(\mathrm{cm}^{-1}\right)$ of lattice, translational $(\mathrm{T})$, rotational (L), and internal modes vibrations active in the Raman spectra, obtained in this work by the B3LYP method, measured experimentally [Exp] and calculated [Theor] in the works of other authors for carbonates with calcite structure, Table S3: Wavenumbers $\left(\mathrm{cm}^{-1}\right)$ of lattice and internal modes vibrations active in the IR spectra, obtained in this work by the B3LYP method, measured experimentally [Exp.] and calculated [Theor.] in the works of other authors for carbonates with dolomite and norsethite structure, Table S4: Wavenumbers $\left(\mathrm{cm}^{-1}\right)$ of lattice and internal modes vibrations active in Raman spectra, obtained in this work by the B3LYP method, measured experimentally [Exp.] and calculated [Theor.] in the works of other authors for carbonates with dolomite and norsethite structure, Table S5: Wavenumbers $\left(\mathrm{cm}^{-1}\right)$ of internal modes $\mathrm{v}_{1}, \mathrm{v}_{2}, \mathrm{v}_{3}, \mathrm{v}_{4}$ vibrations active in infrared spectra (IRS) calculated by the B3LYP method, measured experimentally [Exp.] and calculated [Theor.] in the works of other authors for crystals with aragonite structure, Table S6: Wavenumbers $\left(\mathrm{cm}^{-1}\right)$ of internal modes $\mathrm{v}_{1}, \mathrm{v}_{2}, \mathrm{v}_{3}, \mathrm{v}_{4}$ vibrations active in the Raman spectra, calculated by the B3LYP method, measured experimentally [Exp.] and calculated [Theor.] in the works of other authors for crystals with aragonite structure, Table S7: Wavenumbers $\left(\mathrm{cm}^{-1}\right)$ of lattice vibrations, active in infrared (IR) spectra, calculated by the B3LYP method, measured experimentally [Exp.] and calculated [Theor.] in the works of other authors for crystals with aragonite 
structure, Table S8: Wavanumbers $\left(\mathrm{cm}^{-1}\right)$ of lattice vibrations active in the Raman spectra, calculated by the B3LYP method, experimentally measured [Exp.] and calculated [Theor.] in the works of other authors for crystals with aragonite structure, Table S9: Values of the coefficients $\omega_{0}\left(\mathrm{~cm}^{-1}\right), \omega_{1}\left(\mathrm{~cm}^{-1} / \mathrm{a} . \mathrm{m} . \mathrm{u}.\right)$ of linear interpolation of frequencies $\omega=\omega_{0}+\omega_{1} \cdot \mathrm{M}\left(\mathrm{cm}^{-1}\right)$ by the atomic mass of the metal Mintramolecular $\left(v_{4}, v_{2}, v_{1}, v_{3}\right)$ modes, active in the Raman and infrared spectra absorption (IR) of carbonates with aragonite structure, obtained from theoretical calculations by the B3LYP method. The correlation coefficient $\mathrm{K}$ is shown in parentheses. Table S10: Values of the coefficients $\omega_{0}\left(\mathrm{~cm}^{-1}\right), \omega_{1}\left(\mathrm{~cm}^{-1} /\right.$ a.m.u. $)$ of linear interpolation of wavenumbers $\omega=\omega_{0}+\omega_{1} \cdot M\left(\mathrm{~cm}^{-1}\right)$ by the atomic mass of the metal $\mathrm{M}$ of lattice vibrations active in the Raman spectra of carbonates with aragonite structure obtained from theoretical calculations by the B3LYP method. The correlation coefficient $K$ is shown in parentheses.

Author Contributions: Y.N.Z.: Conceptualization, data curation, paper writing; V.V.A.: Conceptualization, paper writing. Both authors have read and agreed to the published version of the manuscript.

Funding: This work was supported by the Russian Science Foundation (project 19-42-02003, in the part of conceptualization), Ministry of Science and Higher Education of Russia (project 075-15-2020-797 (13.1902.21.0024)) and Kemerovo State University.

Conflicts of Interest: The authors declare no conflict of interest.

\section{References}

1. Liu, Y.; Shen, Y.; Zhao, S.; Luo, J. Structure-property relationship in nonlinear optical materials with p-conjugated $\mathrm{CO}_{3}$ triangles. Coord. Chem. Rev. 2020, 407, 213152. [CrossRef]

2. Hazen, R.M.; Downs, R.T.; Jones, A.P.; Kah, L. Carbon Mineralogy and Crystal Chemistry. Rev. Mineral. Geochem. 2013, 75, 7-46. [CrossRef]

3. Miller, K.G.; Kominz, M.A.; Browning, J.V.; Wright, J.D.; Mountain, G.S.; Katz, M.E.; Sugarman, P.J.; Cramer, B.S.; Christie-Blick, N.; Pekar, S.F. The Phanerozoic Record of Global Sea-Level Change. Science 2005, 310, 1293-1298. [CrossRef]

4. Dupraz, C.; Reid, R.P.; Braissant, O.; Decho, A.W.; Norman, R.S.; Visscher, P.T. Processes of carbonate precipitation in modern microbial mats. Earth-Sci. Rev. 2009, 96, 141-162. [CrossRef]

5. Litasov, K.D.; Goncharov, A.F.; Hemley, R.J. Crossover from melting to dissociation of $\mathrm{CO}_{2}$ under pressure: Implications for the lower mantle. Earth Planet. Sci. Lett. 2011, 309, 318-323. [CrossRef]

6. Litasov, K.D.; Shatskiy, A.; Ohtani, E.; Yaxley, G.M. Solidus of alkaline carbonatite in the deep mantie. Geology 2013, 41, 79-82. [CrossRef]

7. Montañez, I.P.; McElwain, J.C.; Poulsen, C.J.; White, J.D.; DiMichele, W.A.; Wilson, J.P.; Griggs, G.; Hren, M.T. Climate, $\mathrm{pCO}_{2}$ and terrestrial carbon cycle linkages during late Palaeozoic glacial-interglacial cycles. Nat. Geosci. 2016, 9, 824-828. [CrossRef]

8. Sieber, M.J.; Wilke, F.; Koch-Müller, M. Partition coefficients of trace elements between carbonates and melt and suprasolidus phase relation of Ca-Mg-carbonates at 6 GPa. Am. Mineral. 2020, 105, 922-931. [CrossRef]

9. Xie, M.; Yang, L.; Ji, Y.; Wang, Z.; Ren, X.; Liu, Z.; Asiri, A.M.; Xiong, X.; Sun, X. An amorphous Co-carbonate-hydroxide nanowire array for efficient and durable oxygen evolution reaction in carbonate electrolytes. Nanoscale 2017, 9, 16612-16615. [CrossRef]

10. Sobhani-Nasab, A.; Pourmohamadian, H.; Rahimi-Nasrabadi, M.; Sheikhzadeh, G.A.; Tabrizi, H.B. Evaluation of the thermal properties of $\mathrm{SrCO}_{3}$-microencapsulated palmitic acid composites as thermal energy storage materials. J. Therm. Anal. Calorim. 2020, 140, 2123-2130. [CrossRef]

11. De Beauvoir, T.H.; Sangregorio, A.; Cornu, I.; Josse, M. Synthesis, sintering by Cool-SPS and characterization of $\mathrm{A}_{2} \mathrm{Cu}\left(\mathrm{CO}_{3}\right)_{2}(\mathrm{~A}=\mathrm{K}, \mathrm{Na})$ : Evidence for multiferroic and magnetoelectric cupricarbonates. Dalton Trans. 2020, 49, 7820-7828. [CrossRef] [PubMed]

12. Lee, J.; Ryu, K.H.; Ha, H.Y.; Jung, K.-D.; Lee, J.H. Techno-economic and environmental evaluation of nano calcium carbonate production utilizing the steel slag. J. CO2 Util. 2020, 37, 113-121. [CrossRef]

13. Mazhar, S.F.B.; Meyer, H.J.; Samuels, T.; Sharonov, M.; Shi, L.; Alfano, R.R. Exploration of the competition between $\mathrm{O}$ - and E-wave induced stimulated Raman and supercontinuum in calcite under ultrafast laser excitation. Appl. Opt. 2020, 59, 5252-5257. [CrossRef] [PubMed]

14. Karuppaiah, M.; Akilan, R.; Sakthivel, P.; Asaithambi, S.; Shankar, R.; Yuvakkumar, R.; Hayakawa, Y.; Ravi, G. Synthesis of self-essembled micro/nano structured manganese carbonate for high performance, long lifespan asymmetric supercapacitors and investigation of atomic-level intercalation properties of $\mathrm{OH}^{-}$ions via first principle calculation. J. Energy Storage 2020, 27, 101138. [CrossRef] 
15. Assaedi, H.; Alomayri, T.; Kaze, C.R.; Jindal, B.B.; Subaer, S.; Shaikh, F.; Alraddadi, S. Characterization and properties of geopolymer nanocomposites with different contents of nano- $\mathrm{CaCO}_{3}$. Constr. Build. Mater. 2020, 252, 119137. [CrossRef]

16. Atuchin, V.V.; Kesler, V.G.; Kokh, A.E.; Pokrovsky, L.D. X-ray photoelectron spectroscopy study of b-BaB $\mathrm{B}_{2} \mathrm{O}_{4}$ optical surface. Appl. Surf. Sci. 2004, 223, 352-360. [CrossRef]

17. Ramana, C.V.; Vemuri, R.S.; Kaichev, V.V.; Kochubey, V.A.; Saraev, A.A.; Atuchin, V.V. X-ray photoelectron spectroscopy depth profiling of $\mathrm{La}_{2} \mathrm{O}_{3} / \mathrm{Si}$ thin films deposited by reactive magnetron sputtering. ACS Appl. Mater. Interfaces 2011, 3, 4370-4373. [CrossRef]

18. Atuchin, V.V.; Molokeev, M.S.; Yurkin, G.Y.; Gavrilova, T.A.; Kesler, V.G.; Laptash, N.M.; Flerov, I.N.; Patrin, G.S. Synthesis, Structural, Magnetic, and Electronic Properties of Cubic $\mathrm{CsMnMoO}_{3} \mathrm{~F}_{3}$ Oxyfluoride. J. Phys. Chem. C 2012, 116, 10162-10170. [CrossRef]

19. Rubio, E.J.; Atuchin, V.V.; Kruchinin, V.N.; Pokrovsky, L.D.; Prosvirin, I.P.; Ramana, C.V. Electronic Structure and Optical Quality of Nanocrystalline $\mathrm{Y}_{2} \mathrm{O}_{3}$ Film Surfaces and Interfaces on Silicon. J. Phys. Chem. C 2014, 118, 13644-13651. [CrossRef]

20. Atuchin, V.V.; Vinnik, D.; Gavrilova, T.A.; Gudkova, S.; Isaenko, L.I.; Jiang, X.; Pokrovsky, L.D.; Prosvirin, I.P.; Mashkovtseva, L.S.; Lin, Z. Flux Crystal Growth and the Electronic Structure of $\mathrm{BaFe}_{12} \mathrm{O}_{19}$ Hexaferrite. J. Phys. Chem. C 2016, 120, 5114-5123. [CrossRef]

21. Kang, L.; Lin, Z.; Qin, J.; Chen, C. Two novel nonlinear optical carbonates in the dee-ultraviolet region: $\mathrm{KBeCO}_{3} \mathrm{~F}$ and $\mathrm{RbAlCO}_{3} \mathrm{~F}_{2}$. Sci. Rep. 2013, 3, 1366. [CrossRef] [PubMed]

22. Than, T.T.; Young, J.; Rondinelli, J.M.; Halasyamani, P.S. Mixed-metal carbonate fluorides as deep-ultraviolet non-linear optical materials. J. Am. Chem. Soc. 2017, 139, 1285-1295.

23. Zhang, X.; Wu, H.; Cheng, S.; Han, G.; Yang, Z.; Pan, S. $\mathrm{K}_{9}\left[\mathrm{~B}_{4} \mathrm{O}_{5}(\mathrm{OH})_{4}\right]_{3}\left(\mathrm{CO}_{3}\right) \mathrm{X} \times 7 \mathrm{H}_{2} \mathrm{O}(\mathrm{X}=\mathrm{Cl}$, Br): Synthesis, characterizations, and theoretical studies of noncentrosymmetric halogen borate-carbonates with short UV cutoff edges. Inorg. Chem. 2019, 58, 6974-6982. [CrossRef] [PubMed]

24. Peng, G.; Lin, C.S.; Yang, Y.; Zhao, D.; Lin, Z.; Ye, N.; Huang, J.S. $\mathrm{Y}_{2}\left(\mathrm{CO}_{3}\right)_{3} \times \mathrm{H}_{2} \mathrm{O}$ and $\left(\mathrm{NH}_{4}\right)_{2} \mathrm{Ca}_{2} \mathrm{Y}_{4}\left(\mathrm{CO}_{3}\right)_{9} \times \mathrm{H}_{2} \mathrm{O}$ : Partial aviovalent cation substitution enabling evolution from centrosymmetry to noncentrosymmetry for nonlinear optical response. Chem. Mater. 2019, 31, 52-56. [CrossRef]

25. Chen, K.; Peng, G.; Lin, C.; Luo, M.; Fan, H.; Yang, S.; Ye, N. NaPb $2\left(\mathrm{CO}_{3}\right)_{2} \mathrm{~F}_{2}(\mathrm{OH})_{1-\mathrm{x}}(0<\mathrm{x} \leq 1)$ : A new member of alkali-lead carbonate fluoride system with large birefringence. J. Solid State Chem. 2020, 288, 121407. [CrossRef]

26. Zou, G.; Ok, K.M. Novel ultraviolet (UV) nonlinear optical (NLO) materials discovered by chemical substitution-oriented design. Chem. Sci. 2020, 11, 5404-5409. [CrossRef]

27. Gong, P.; Liu, X.; Kang, L.; Lin, Z. Inorganic planar p-conjugated groups in nonlinear optical crystals: Review and outlook. Inorg. Chem. Front. 2020, 7, 839-952. [CrossRef]

28. Dorfman, S.M.; Badro, J.; Nabiei, F.; Prakapenka, V.B.; Cantoni, M.; Gillet, P. Carbonate stability in the reduced lower mantle. Earth Planet. Sci. Lett. 2018, 489, 84-91. [CrossRef]

29. Zolotoyabko, E.; Caspi, E.N.; Fieramosca, J.S.; Von Dreele, R.B.; Marin, F.; Mor, G.; Addadi, L.; Weiner, S.; Politi, Y. Differences between Bond Lengths in Biogenic and Geological Calcite. Cryst. Growth Des. 2010, 10, 1207-1214. [CrossRef]

30. Liang, W.; Li, Z.; Yin, Y.; Li, R.; Chen, L.; He, Y.; Dong, H.; Dai, L.; Li, H. Single crystal growth, characterization and high-pressure Raman spectroscopy of impurity-free magnesite $\left(\mathrm{MgCO}_{3}\right)$. Phys. Chem. Miner. 2018, 45, 423-434. [CrossRef]

31. Liang, W.; Yin, Y.; Li, Z.; Li, R.; Li, L.; He, Y.; Dong, H.; Li, Z.; Yan, S.; Zhai, S.; et al. Single crystal growth, crystalline structure investigation and high-pressure behavior of impurity-free siderite $\left(\mathrm{FeCO}_{3}\right)$. Phys. Chem. Miner. 2018, 45, 831-842. [CrossRef]

32. Gao, J.; Zhu, F.; Lai, X.-J.; Huang, R.; Qin, S.; Chen, D.; Liu, J.; Zheng, L.-R.; Wu, X. Compressibility of a natural smithsonite $\mathrm{ZnCO}_{3}$ up to $50 \mathrm{GPa}$. High Press. Res. 2014, 34, 89-99. [CrossRef]

33. Liang, W.; Li, L.; Li, R.; Yin, Y.; Li, Z.; Liu, X.; Shan, S.; He, Y.; Meng, Y.; Li, Z.; et al. Crystal structure of impurity-free rhodochrosite $\left(\mathrm{MnCO}_{3}\right)$ and thermal expansion properties. Phys. Chem. Miner. 2020, 47, 1-11. [CrossRef]

34. Chariton, S.; Cerantola, V.; Ismailova, L.; Bykova, E.; Bykov, M.; Kupenko, I.; McCammon, C.; Dubrovinsky, L.S. The high-pressure behavior of spherocobaltite $\left(\mathrm{CoCO}_{3}\right)$ : A single crystal Raman spectroscopy and XRD study. Phys. Chem. Miner. 2018, 45, 59-68. [CrossRef] 
35. Reddy, B.J.; Frost, R.L. Electronic and vibrational spectra of gaspeite. Neues Jahrb. Mineral. Mon. 2004, 525-536. [CrossRef]

36. Liu, L.G.; Lin, C.C. A Calcite $\rightarrow$ aragonite-type phase transition in $\mathrm{CdCO}_{3}$. Am. Mineral. 1997, 82, $643-646$. [CrossRef]

37. Liu, Z.T.Y.; Burton, B.P.; Khare, S.V.; Sarin, P. First-principles phase diagram calculations for the carbonate quasibinary systems $\mathrm{CaCO}_{3}-\mathrm{ZnCO}_{3}, \mathrm{CdCO}_{3}-\mathrm{ZnCO}_{3}, \mathrm{CaCO}_{3}-\mathrm{CdCO}_{3}$ and $\mathrm{MgCO}_{3}-\mathrm{ZnCO}_{3}$. Chem. Geol. 2016, 443, 137-145. [CrossRef]

38. Zucchini, A.; Comodi, P.; Nazzareni, S.; Hanfland, M. The effect of cation ordering and temperature on the high-pressure behaviour of dolomite. Phys. Chem. Miner. 2014, 41, 783-793. [CrossRef]

39. Garavelli, C.G.; Vurro, F.; Fioravanti, G.C. Minrecordite, a new mineral from Tsumeb. Mineral. Rec. 1982, 13, 131-136.

40. Chai, L.; Navrotsky, A. Synthesis, characterization, and energetics of solid solution along the dolomite-ankerite join, and implications for the stability of ordered $\mathrm{CaFe}\left(\mathrm{CO}_{3}\right)_{2}$. Am. Mineral. 1996, 81, 1141-1147. [CrossRef]

41. Frondel, C.; Bauer, C.L.H. Kutnahorite: A manganese dolomite, CaMn $\left(\mathrm{CO}_{3}\right)_{2}$. Am. Mineral. 1955, 40, 748-760.

42. Tareen, J.A.K.; Fazeli, A.R.; Basavalingu, B.; Bhandige, G.T. Decarbonation curves and associated thermodynamic data for synthetic Cd-dolomites $\mathrm{CdMg}\left(\mathrm{CO}_{3}\right)_{2}, \mathrm{CdMn}\left(\mathrm{CO}_{3}\right)_{2}$ and $\mathrm{CdZn}\left(\mathrm{CO}_{3}\right)_{2}$. J. Therm. Anal. 1995, 44, 937-954. [CrossRef]

43. Bromiley, F.A.; Ballaran, T.B.; Langenhorst, F.; Seifert, F. Order and miscibility in the otavite-magnesite solid solution. Am. Mineral. 2007, 92, 829-836. [CrossRef]

44. Effenberger, H.; Zemann, J. Single crystal X-ray investigation of norsethite, $\mathrm{BaMg}\left(\mathrm{CO}_{3}\right)_{2}$ : One more mineral with an aplanar carbonate group. Z. Krist. 1985, 171, 275-280. [CrossRef]

45. Liang, W.; Li, L.; Yin, Y.; Li, R.; Li, Z.; Liu, X.; Zhao, C.; Yang, S.; Meng, Y.; Li, Z.; et al. Crystal structure of norsethite-type BaMn $\left(\mathrm{CO}_{3}\right)_{2}$ and its pressure-induced transition investigated by Raman spectroscopy. Phys. Chem. Miner. 2019, 46, 771-781. [CrossRef]

46. Pippinger, T.; Miletich, R.; Effenberger, H.; Hofer, G.; Lotti, P.; Merlini, M. High-pressure polymorphism and structural transitions of norsethite, $\mathrm{BaMg}\left(\mathrm{CO}_{3}\right)_{2}$. Phys. Chem. Miner. 2014, 41, 737-755. [CrossRef]

47. Antao, S.M.; Hassan, I. The orthorhombic structure of $\mathrm{CaCO}_{3}, \mathrm{SrCO}_{3}, \mathrm{PbCO}_{3}$ and $\mathrm{BaCO}_{3}$ : Linear structure trends. Can. Mineral. 2009, 47, 1245-1255. [CrossRef]

48. Ye, Y.; Smyth, J.R.; Boni, P. Crystal structure and thermal expansion of aragonite-group carbonates by single-crystal X-ray diffraction. Am. Mineral. 2012, 97, 707-712. [CrossRef]

49. Kaabar, W.; Bott, S.; Devonshire, R. Raman spectroscopic study of mixed carbonate materials. Spectrochim. Acta A 2011, 78, 136-141. [CrossRef]

50. Litasov, K.; Shatskiy, A.; Gavryushkin, P.N.; Bekhtenova, A.; Dorogokupets, P.I.; Danilov, B.S.; Higo, Y.; Akilbekov, A.T.; Inerbaev, T.M. P-V-T equation of state of $\mathrm{CaCO}_{3}$ aragonite to $29 \mathrm{GPa}$ and $1673 \mathrm{~K}$ : In situ X-ray diffraction study. Phys. Earth Planet. Inter. 2017, 265, 82-91. [CrossRef]

51. Lobanov, S.S.; Dong, X.; Martirosyan, N.S.; Samtsevich, A.I.; Stevanovic, V.; Gavryushkin, P.N.; Litasov, K.D.; Greenberg, E.; Prakapenka, V.B.; Oganov, A.R.; et al. Raman spectroscopy and x-ray diffraction of sp3CaCO3 at lower mantle pressures. Phys. Rev. B 2017, 96, 104101. [CrossRef]

52. Smith, D.; Lawler, K.V.; Martinez-Canales, M.; Daykin, A.W.; Fussell, Z.; Smith, G.A.; Childs, C.; Smith, J.S.; Pickard, C.J.; Salamat, A. Postaragonite phases of $\mathrm{CaCO}_{3}$ at lower mantle pressures. Phys. Rev. Mater. 2018, 2, 013605. [CrossRef]

53. Zhang, Z.; Mao, Z.; Liu, X.; Zhang, Y.; Brodholt, J.P. Stability and Reactions of $\mathrm{CaCO}_{3}$ polymorphs in the Earth's Deep Mantle. J. Geophys. Res. Solid Earth 2018, 123, 6491-6500. [CrossRef]

54. Zhu, Y.; Li, Y.; Ding, H.; Lu, A.; Li, Y.; Wang, C. Infrared emission properties of a kind of natural carbonate: Interpretation from mineralogical analysis. Phys. Chem. Miner. 2020, 47, 1-15. [CrossRef]

55. Weir, C.E.; Lippincott, E.R. Infrared studies of aragonite, calcite, and vaterite type structures in the borates, carbonates, and nitrates. J. Res. Natl. Bur. Stand. Sect. A Phys. Chem. 1961, 65, 173-180. [CrossRef]

56. Bischoff, W.D.; Sharma, S.K.; Mackenzie, F.T. Carbonate ion disorder in synthetic and biogenic magnesian calcites-A Raman spectral study. Am. Mineral. 1985, 70, 581-589.

57. Lin, C.-C.; Liu, L.-G. Post-aragonite phase transitions in strontianite and cerussite-A high pressure Raman spectroscopic study. J. Phys. Chem. Solids 1997, 58, 977-987. [CrossRef] 
58. Valenzano, L.; Noël, Y.; Orlando, R.; Zicovich-Wilson, C.M.; Ferrero, M.; Dovesi, R. Ab initio vibrational spectra and dielectric properties of carbonates: Magnesite, calcite and dolomite. Theor. Chem. Acc. 2007, 117, 991-1000. [CrossRef]

59. Kalinin, N.V.; Saleev, V.A. Ab initio modeling of Raman and infrared spectra of calcite. Comput. Opt. 2018, 42, 263-266. [CrossRef]

60. Sun, J.; Wu, Z.; Cheng, H.; Zhang, Z.; Frost, R.L. A Raman spectroscopic comparison of calcite and dolomite. Spectrochim. Acta Part A Mol. Biomol. Spectrosc. 2014, 117, 158-162. [CrossRef]

61. Perrin, J.; Vielzeuf, D.; Laporte, D.; Ricolleau, A.; Rossman, G.R.; Floquet, N. Raman characterization of synthetic magnesian calcites. Am. Mineral. 2016, 101, 2525-2538. [CrossRef]

62. Liu, J.; Caracas, R.; Fan, D.; Bobocioiu, E.; Zhang, D.; Mao, W.L. High-pressure compressibility and vibrational properties of (Ca,Mn) $\mathrm{CO}_{3}$. Am. Mineral. 2016, 101, 2723-2730. [CrossRef]

63. Minch, R.; Seoung, D.-H.; Ehm, L.; Winkler, B.; Knorr, K.; Peters, L.; Borkowski, L.; Parise, J.B.; Lee, Y.; Dubrovinsky, L.S.; et al. High-pressure behavior of otavite $\left(\mathrm{CdCO}_{3}\right)$. J. Alloy Compd. 2010, 508, $251-257$. [CrossRef]

64. Dufresne, W.J.; Rufledt, C.J.; Marshall, C.P. Raman spectroscopy of the eight natural carbonate minerals of calcite structure. J. Raman Spectrosc. 2018, 49, 1999-2007. [CrossRef]

65. Efthimiopoulos, I.; Germer, M.; Jahn, S.; Harms, M.; Reichmann, H.J.; Speziale, S.; Schade, U.; Sieber, M.; Koch-Müller, M. Effects of hydrostaticity on the structural stability of carbonates at lower mantle pressures: The case study of dolomite. High Press. Res. 2018, 39, 36-49. [CrossRef]

66. Efthimiopoulos, I.; Jahn, S.; Kuras, A.; Schade, U.; Koch-Müller, M. Combined high-pressure and high-temperature vibrational studies of dolomite: Phase diagram and evidence of a new distorted modification. Phys. Chem. Miner. 2017, 44, 465-476. [CrossRef]

67. Martens, W.N.; Rintoul, L.; Kloprogge, J.T.; Frost, R.L. Single crystal raman spectroscopy of cerussite. Am. Mineral. 2004, 89, 352-358. [CrossRef]

68. Wang, X.; Ye, Y.; Wu, X.; Smyth, J.R.; Yang, Y.; Zhang, Z.; Wang, Z. High-temperature Raman and FTIR study of aragonite-group carbonates. Phys. Chem. Miner. 2018, 46, 51-62. [CrossRef]

69. Efthimiopoulos, I.; Müller, J.; Winkler, B.; Otzen, C.; Harms, M.; Schade, U.; Koch-Müller, M. Vibrational response of strontianite at high pressures and high temperatures and construction of $\mathrm{P}-\mathrm{T}$ phase diagram. Phys. Chem. Miner. 2019, 46, 27-35. [CrossRef]

70. Lane, M.D.; Christensen, P.R. Thermal infrared emission spectroscopy of anhydrous carbonates. J. Geophys. Res. 1997, 102, 25581-25592. [CrossRef]

71. Deines, P. Carbon isotope effects in carbonate systems. Geochim. Cosmochim. Acta 2004, 68, $2659-2679$. [CrossRef]

72. Brusentsova, T.N.; Peale, R.E.; Maukonen, D.; Harlow, G.E.; Boesenberg, J.S.; Ebel, D.; Prêt, D.; Sammartino, S.; Beaufort, D.; Fialin, M.; et al. Far infrared spectroscopy of carbonate minerals. Am. Mineral. 2010, 95, 1515-1522. [CrossRef]

73. Farsang, S.; Facq, S.; Redfern, S.A.T. Raman modes of carbonate minerals as pressure and temperature gauges up to $6 \mathrm{GPa}$ and $500{ }^{\circ} \mathrm{C}$. Am. Mineral. 2018, 103, 1988-1998. [CrossRef]

74. Erba, A.; Baima, J.; Bush, I.; Orlando, R.; Dovesi, R. Large-Scale Condensed Matter DFT Simulations: Performance and Capabilities of the CRYSTAL Code. J. Chem. Theory Comput. 2017, 13, 5019-5027. [CrossRef] [PubMed]

75. Dovesi, R.; Erba, A.; Orlando, R.; Zicovich-Wilson, C.M.; Civalleri, B.; Maschio, L.; Rérat, M.; Casassa, S.; Baima, J.; Salustro, S.; et al. Quantum-mechanical condensed matter simulations with CRYSTAL. Wiley Interdiscip. Rev. Comput. Mol. Sci. 2018, 8, e1360. [CrossRef]

76. Becke, A.D. Density functional thermochemistry. III. The role of exact exchange. J. Chem. Phys. 1993, 98, 5648-5652. [CrossRef]

77. Lee, C.; Yang, W.; Parr, R.G. Development of the Colle-Salvetti correlation-energy formula into a functional of the electron density. Phys. Rev. B 1988, 37, 785-789. [CrossRef]

78. Valenzano, L.; Torres, F.J.; Doll, K.; Pascale, F.; Zicovich-Wilson, C.M.; Dovesi, R. Ab InitioStudy of the Vibrational Spectrum and Related Properties of Crystalline Compounds; the Case of $\mathrm{CaCO}_{3}$ Calcite. Z. Phys. Chem. 2006, 220, 893-912. [CrossRef]

79. Peintinger, M.F.; Oliveira, D.V.; Bredow, T. Consistent Gaussian basis sets of triple-zeta valence with polarization quality for solid-state calculations. J. Comput. Chem. 2013, 34, 451-459. [CrossRef] 
80. Laun, J.; Oliveira, D.V.; Bredow, T. Consistent gaussian basis sets of double- and triple-zeta valence with polarization quality of the fifth period for solid-state calculations. J. Comput. Chem. 2018, 39, 1285-1290. [CrossRef]

81. Piskunov, S.; Heifets, E.; Eglitis, R.; Borstel, G. Bulk properties and electronic structure of $\mathrm{SrTiO}_{3}, \mathrm{BaTiO}_{3}$, $\mathrm{PbTiO}_{3}$ perovskites: An ab initio HF/DFT study. Comput. Mater. Sci. 2004, 29, 165-178. [CrossRef]

82. Evarestov, R.; Kotomin, E.A.; Mastrikov, Y.; Gryaznov, D.; Heifets, E.; Maier, J. Comparative density-functional LCAO and plane-wave calculations ofLaMnO3surfaces. Phys. Rev. B 2005, 72, 214411. [CrossRef]

83. Sophia, G.; Baranek, P.; Sarrazin, C.; Rérat, M.; Dovesi, R. First-principles study of the mechanisms of the pressure-induced dielectric anomalies in ferroelectric perovskites. Phase Transit. 2013, 86, 1069-1084. [CrossRef]

84. Monkhorst, H.J.; Pack, J.D. Special points for Brillouin-zone integrations. Phys. Rev. B 1976, 13, 5188. [CrossRef]

85. Pascale, F.; Zicovich-Wilson, C.M.; Gejo, F.L.; Civalleri, B.; Orlando, R.; Dovesi, R. The calculation of the vibrational frequencies of crystalline compounds and its implementation in the CRYSTAL code. J. Comput. Chem. 2004, 25, 888-897. [CrossRef] [PubMed]

86. Zicovich-Wilson, C.M.; Pascale, F.; Roetti, C.; Saunders, V.R.; Orlando, R.; Dovesi, R. Calculation of the vibration frequencies of alpha-quartz: The effect of Hamiltonian and basis set. J. Comput. Chem. 2004, 25, 1873-1881. [CrossRef] [PubMed]

87. Carteret, C.; De La Pierre, M.; Dossot, M.; Pascale, F.; Erba, A.; Dovesi, R. The vibrational spectrum of $\mathrm{CaCO}_{3}$ aragonite: A combined experimental and quantum-mechanical investigation. J. Chem. Phys. 2013, 138, 014201. [CrossRef]

88. Baima, J.; Ferrabone, M.; Orlando, R.; Erba, A.; Dovesi, R. Thermodynamics and phonon dispersion of pyrope and grossular silicate garnets from ab initio simulations. Phys. Chem. Miner. 2016, 43, 137-149. [CrossRef]

89. Maschio, L.; Kirtman, B.; Rérat, M.; Orlando, R.; Dovesi, R. Ab initio analytical Raman intensities for periodic systems through a coupled perturbed Hartree-Fock/Kohn-Sham method in an atomic orbital basis. II. Validation and comparison with experiments. J. Chem. Phys. 2013, 139, 164102. [CrossRef]

90. Korabel'Nikov, D.; Zhuravlev, Y.N. Structural, elastic, electronic and vibrational properties of a series of sulfates from first principles calculations. J. Phys. Chem. Solids 2018, 119, 114-121. [CrossRef]

91. Shannon, R.D. Revised effective ionic radii and systematic studies of interatomic distances in halides and chalcogenides. Acta Crystallogr. Sect. A 1976, 32, 751-767. [CrossRef]

92. Grzechnik, A.; Simon, P.; Gillet, P.; McMillan, P. An infrared study of $\mathrm{MgCO}_{3}$ at high pressure. Phys. $B$ Condens. Matter 1999, 262, 67-73. [CrossRef]

93. Clark, S.J.; Jouanna, P.; Haines, J.; Mainprice, D. Calculation of infrared and Raman vibration modes of magnesite at high pressure by density-functional perturbation theory and comparison with experiments. Phys. Chem. Miner. 2010, 38, 193-202. [CrossRef]

94. Yao, C.; Wu, Z.; Zou, F.; Sun, W. Thermodynamic and Elastic Properties of Magnesite at Mantle Conditions: First-Principles Calculations. Geochem. Geophys. Geosyst. 2018, 19, 2719-2731. [CrossRef]

95. Gillet, P.; Biellmann, C.; Reynard, B.; McMillan, P. Raman spectroscopic studies of carbonates part I: High-pressure and high-temperature behaviour of calcite, magnesite, dolomite and aragonite. Phys. Chem. Miner. 1993, 20, 1-18. [CrossRef]

96. Schauble, E.A.; Ghosh, P.; Eiler, J.M. Preferential formation of $13 \mathrm{C}-18 \mathrm{O}$ bonds in carbonate minerals, estimated using first-principles lattice dynamics. Geochim. Cosmochim. Acta 2006, 70, 2510-2529. [CrossRef]

97. De La Pierre, M.; Carteret, C.; Maschio, L.; André, E.; Orlando, R.; Dovesi, R. The Raman spectrum of CaCO3polymorphs calcite and aragonite: A combined experimental and computational study. J. Chem. Phys. 2014, 140, 164509. [CrossRef]

98. Spivak, A.V.; Solopova, N.; Cerantola, V.; Bykova, E.; Zakharchenko, E.; Dubrovinsky, L.S.; Litvin, Y. Raman study of $\mathrm{MgCO}_{3}-\mathrm{FeCO}_{3}$ carbonate solid solution at high pressures up to $55 \mathrm{GPa}$. Phys. Chem. Miner. 2014, 41, 633-638. [CrossRef]

99. Siva, T.; Muralidharan, S.; Sathiyanarayanan, S.; Manikandan, E.; Jayachandran, M. Enhanced Polymer Induced Precipitation of Polymorphous in Calcium Carbonate: Calcite Aragonite Vaterite Phases. J. Inorg. Organomet. Polym. Mater. 2017, 27, 770-778. [CrossRef]

100. Farfan, G.A.; Boulard, E.; Wang, S.; Mao, W.L. Bonding and electronic changes in rhodochrosite at high pressure. Am. Mineral. 2013, 98, 1817-1823. [CrossRef] 
101. Zhao, C.; Li, H.; Jiangb, J.; He, Y.; Liang, W. Phase Transition and vibration properties of $\mathrm{MnCO}_{3}$ at high pressure and high-temperature by Raman spectroscopy. High Press. Res. 2018, 38, 212-223. [CrossRef]

102. Böttcher, M.E.; Gehlken, P.-L.; Skogby, H.; Reutel, C. The vibrational spectra of $\mathrm{BaMg}\left(\mathrm{CO}_{3}\right)_{2}$ (norsethite). Miner. Mag. 1997, 61, 249-256. [CrossRef]

103. Chaney, J.; Santillán, J.D.; Knittle, E.; Williams, Q. A high-pressure infrared and Raman spectroscopic study of $\mathrm{BaCO}_{3}$ : The aragonite, trigonal and Pmmn structures. Phys. Chem. Miner. 2015, 42, 83-93. [CrossRef]

104. Brooker, M.H.; Sunder, S.; Taylor, P.; Lopata, V.J. Infrared and Raman spectra and X-ray diffraction studies of solid lead(II) carbonates. Can. J. Chem. 1982, 61, 494-502. [CrossRef]

105. Catalli, K.; Santillán, J.; Williams, Q. A high pressure infrared spectroscopic study of $\mathrm{PbCO}_{3}$-cerussite: Constraints on the structure of the post-aragonite phase. Phys. Chem. Miner. 2005, 32, 412-417. [CrossRef]

106. Frech, R.; Wang, E.C.; Bates, J.B. The i.r. and Raman spectra of $\mathrm{CaCO}_{3}$ (aragonite). Spectrochim. Acta Part A Mol. Spectrosc. 1980, 36, 915-919. [CrossRef]

107. Bayarjargal, L.; Fruhner, C.-J.; Schrodt, N.; Winkler, B. $\mathrm{CaCO}_{3}$ phase diagram studied with Raman spectroscopy at pressures up to $50 \mathrm{GPa}$ and high temperatures and DFT modeling. Phys. Earth Planet. Inter. 2018, 281, 31-45. [CrossRef]

108. Biedermann, N.; Speziale, S.; Winkler, B.; Reichmann, H.J.; Koch-Müller, M.; Heide, G. High-pressure phase behavior of $\mathrm{SrCO}_{3}$ : An experimental and computational Raman scattering study. Phys. Chem. Miner. 2017, 44, 335-343. [CrossRef]

109. Minch, R.; Dubrovinsky, L.S.; Kurnosov, A.; Ehm, L.; Knorr, K.; Depmeier, W. Raman spectroscopic study of $\mathrm{PbCO}_{3}$ at high pressures and temperatures. Phys. Chem. Miner. 2010, 37, 45-56. [CrossRef]

110. Alía, J.M.; de Mera, Y.D.; Edwards, H.G.M.; Martín, P.G.; Andres, S.L. FT-Raman and infrared spectroscopic study of aragonite-strontianite $\left(\mathrm{CaxSr}_{1-x} \mathrm{CO}_{3}\right)$ solid solution. Spectrochim. Acta Part A Mol. Biomol. Spectrosc. 1997, 53, 2347-2362. [CrossRef]

Publisher's Note: MDPI stays neutral with regard to jurisdictional claims in published maps and institutional affiliations.

(C) 2020 by the authors. Licensee MDPI, Basel, Switzerland. This article is an open access article distributed under the terms and conditions of the Creative Commons Attribution (CC BY) license (http://creativecommons.org/licenses/by/4.0/). 